\title{
The Interplay between the RNA Decay and Translation Machinery in Eukaryotes
}

\author{
Adam M. Heck ${ }^{1,2}$ and Jeffrey Wilusz ${ }^{1,2}$ \\ ${ }^{1}$ Department of Microbiology, Immunology and Pathology, Colorado State University, Fort Collins, Colorado \\ 80525 \\ ${ }^{2}$ Program in Cell \& Molecular Biology, Colorado State University, Fort Collins, Colorado 80525 \\ Correspondence: jeffrey.wilusz@colostate.edu
}

RNA decay plays a major role in regulating gene expression and is tightly networked with other aspects of gene expression to effectively coordinate post-transcriptional regulation. The goal of this work is to provide an overview of the major factors and pathways of general messenger RNA (mRNA) decay in eukaryotic cells, and then discuss the effective interplay of this cytoplasmic process with the protein synthesis machinery. Given the transcript-specific and fluid nature of mRNA stability in response to changing cellular conditions, understanding the fundamental networking between RNA decay and translation will provide a foundation for a complete mechanistic understanding of this important aspect of cell biology.

$\mathrm{R}_{\text {lat }}^{\mathrm{N}}$ NA degradation plays a major role in regulating both the quantity and quality of gene expression in the cell. The abundance of an RNA transcript is a reflection of both its rate of synthesis and degradation. There are numerous examples in the literature regarding the regulation of gene expression associated with major cellular responses occurring at the level of differential RNA stability (Chen and Shyu 2017). In addition, there is a growing body of evidence to suggest that cross-communication or buffering occurs between transcription and RNA decay that contributes to the homeostasis of gene expression (Chavèz et al. 2016). The process of translating messenger RNA (mRNA) is also intimately intertwined with the fate of the transcript (Radhakrishnan and Green 2016). Thus, understanding the interplay or networking between the RNA decay machinery and other aspects of gene expression is needed to further elucidate the depth of regulation that occurs in cells. The goal of this work is to provide an up-todate overview of the factors and mechanisms of general mRNA decay and then focus on the interplay of this process with the translational machinery. An overview of key enzymes and factors involved in eukaryotic mRNA decay can be found in Table 1 .

\section{THE MAJOR STEPS AND MECHANISMS OF MRNA DECAY IN EUKARYOTES}

\section{Step One: Deadenylation/Removal of the Poly(A) Tail}

Deadenylation is the initial, and often considered rate-limiting step of the traditional exonucleolytic decay pathways. Deadenylases are

Editors: Michael B. Mathews, Nahum Sonenberg, and John W.B. Hershey

Additional Perspectives on Translation Mechanisms and Control available at www.cshperspectives.org

Copyright (C) 2018 Cold Spring Harbor Laboratory Press; all rights reserved; doi: 10.1101/cshperspect.a032839

Cite this article as Cold Spring Harb Perspect Biol 2018;10:a032839 
A.M. Heck and J. Wilusz

Table 1. An overview of key enzymes and factors involved in eukaryotic mRNA decay

\begin{tabular}{|c|c|c|}
\hline Protein name & Full name & Function \\
\hline \multicolumn{3}{|l|}{ Deadenylation } \\
\hline PAN2 & $\begin{array}{l}\text { Poly(A)-nuclease } \\
\quad \text { deadenylation subunit } 2\end{array}$ & $\begin{array}{l}\text { Enzymatically active subunit of the PAN } 2 / 3 \text { complex that is } \\
\text { responsible for the preliminary poly }(\mathrm{A}) \text { trimming }\end{array}$ \\
\hline PAN3 & $\begin{array}{l}\text { Poly(A)-nuclease } \\
\quad \text { deadenylation subunit } 3\end{array}$ & $\begin{array}{l}\text { Cofactor and regulatory subunit of the PAN } 2 / 3 \text { complex that is } \\
\text { responsible for the preliminary poly }(\mathrm{A}) \text { trimming }\end{array}$ \\
\hline $\begin{array}{l}\text { CNOT6 } \\
\quad(\text { CCR4 })\end{array}$ & $\begin{array}{l}\text { CCR4-NOT complex } \\
\text { subunit } 6\end{array}$ & $\begin{array}{l}3^{\prime} \text { to } 5^{\prime} \text { exonuclease that is the major catalytically active } \\
\text { component of the CCR4-NOT complex that performs most } \\
\text { of mRNA deadenylation }\end{array}$ \\
\hline $\begin{array}{l}\text { CNOT1 } \\
\quad(\text { NOT1) }\end{array}$ & $\begin{array}{l}\text { CCR4-NOT complex } \\
\text { subunit } 1\end{array}$ & $\begin{array}{l}\text { Scaffolding component of the CCR4-NOT deadenylation } \\
\text { complex }\end{array}$ \\
\hline $\begin{array}{l}\text { CNOT7 } \\
\text { (CAF1/ } \\
\text { POP2) }\end{array}$ & $\begin{array}{l}\text { CCR4-NOT complex } \\
\text { subunit } 7\end{array}$ & $\begin{array}{l}\text { Minor deadenylase in the CCR4-NOT complex; its function is } \\
\text { somewhat redundant to CNOT6 (CCR4) }\end{array}$ \\
\hline PARN & Poly(A)-specific ribonuclease & $\begin{array}{l}3^{\prime} \text { to } 5^{\prime} \text { exoribonuclease that interacts with the } 5^{\prime} \text { cap and } \\
\text { preferentially degrades poly }(\mathrm{A}) \text { tails }\end{array}$ \\
\hline \multicolumn{3}{|r|}{ 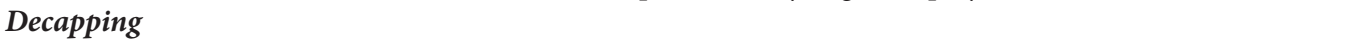 } \\
\hline DCP2 & Decapping protein 2 & $\begin{array}{l}\text { Catalytically active component of the decapping complex that } \\
\text { removes the } 5^{\prime} \text { mRNA cap through hydrolysis reaction }\end{array}$ \\
\hline DCP1 & Decapping protein 1 & $\begin{array}{l}\text { Primary cofactor for DCP2; it enhances hydrolysis activity of } \\
\text { DCP2 and interacts with other proteins to recruit DCP } 1 / 2 \\
\text { complex to mRNA substrates }\end{array}$ \\
\hline PATL1 (Pat1) & PAT1 homolog protein 1 & $\begin{array}{l}\text { Scaffolding protein in deadenylation-dependent decapping; it } \\
\text { connects decapping and deadenylation machinery }\end{array}$ \\
\hline Lsm1-7 & Sm-like protein complex & $\begin{array}{l}\text { Identifies and associates with deadenylated transcripts; it } \\
\text { interacts with PALT1 to recruit the DCP } 1 / 2 \text { complex }\end{array}$ \\
\hline DDX6 (Dhh1) & DEAD-box helicase 6 & $\begin{array}{l}\text { RNA helicase enzyme that interacts with other decapping } \\
\text { factors and is thought to remodel the transcript to promote } \\
\text { efficient decapping complex assembly }\end{array}$ \\
\hline LSM14 (Scd6) & Sm-like protein 14 & $\begin{array}{l}\text { Serve as a scaffold for assembly and activation of DCP } 1 / 2 \\
\text { complex }\end{array}$ \\
\hline $\mathrm{EDC} 1,2,3$ & $\begin{array}{l}\text { Enhancer of mRNA- } \\
\text { decapping proteins }\end{array}$ & $\begin{array}{l}\text { Serve as a scaffold for assembly and activation of DCP } 1 / 2 \\
\text { complex }\end{array}$ \\
\hline \multicolumn{3}{|r|}{ 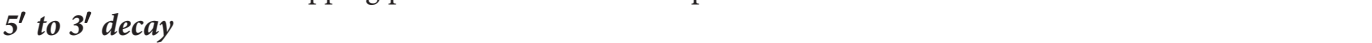 } \\
\hline XRN1 & $5^{\prime}-3^{\prime}$ exoribonuclease & $\begin{array}{l}\text { Major } 5^{\prime} \text { to } 3^{\prime} \text { exoribonuclease that preferentially degrades } \\
\text { RNAs with a } 5^{\prime} \text { monophosphate }\end{array}$ \\
\hline \multicolumn{3}{|l|}{$3^{\prime}$ to $5^{\prime}$ decay } \\
\hline Exo9 & $\begin{array}{l}\text { Exosome complex } \\
\quad \text { (9-subunit) }\end{array}$ & $\begin{array}{l}\text { The core of the exosome that consists of nine different protein } \\
\text { subunits }\end{array}$ \\
\hline RRP44 & $\begin{array}{l}\text { Exosome complex } \\
\quad \text { exonuclease RRP44 }\end{array}$ & Catalytically active subunit of the exosome \\
\hline SKI7 & Superkiller protein 7 & $\begin{array}{l}\text { GTP-binding protein that recruits the exosome to nonpoly(A) } \\
\text { mRNAs; it is involved in several, including NSD, NMD, and } \\
\text { antiviral activity }\end{array}$ \\
\hline DCPS & Decapping scavenger enzyme & $\begin{array}{l}\text { Catalyzes the cleavage of the residual } 5^{\prime} \text { cap from short } \\
\text { oligonucleotide sequence following } 3^{\prime} \text { to } 5^{\prime} \text { decay }\end{array}$ \\
\hline DIS3L2 & DIS3-like exonuclease 2 & $\begin{array}{l}3^{\prime} \text { to } 5^{\prime} \text { exoribonuclease that specifically recognizes } \\
\text { polyuridylated RNAs and mediates their degradation }\end{array}$ \\
\hline TUT4/7 & $\begin{array}{l}\text { Terminal uridyltransferase } \\
\quad 4 / 7\end{array}$ & $\begin{array}{l}\text { Uridyltransferases that mediate terminal uridylation of } \\
\text { mRNAs with short poly(A) tails, thus facilitating their } \\
\text { degradation }\end{array}$ \\
\hline
\end{tabular}


RNA Decay and Translation

Table 1. Continued

\begin{tabular}{lcc}
\hline Protein name & Full name & Function \\
\hline $\begin{array}{l}\text { Endonucleolytic decay } \\
\text { MCPIP1 }\end{array}$ & $\begin{array}{c}\text { Regnase 1/endoribonuclease } \\
\text { ZC3H12A }\end{array}$ & $\begin{array}{c}\text { Endonuclease that facilitates mRNA decay and is linked to } \\
\text { various biological functions, including immune and } \\
\text { inflammatory responses }\end{array}$ \\
HRSP12 & Heat-responsive protein 12 & $\begin{array}{c}\text { Protein with endonuclease activity that is involved in activity } \\
\text { and formation of the GMD complex }\end{array}$ \\
IRE-1 & Inositol-requiring enzyme 1 & $\begin{array}{c}\text { Endonuclease that targets a series of mRNAs connected to } \\
\text { several cellular processes }\end{array}$ \\
RNase L & $\begin{array}{c}\text { Ribonuclease L or } \\
\text { ribonuclease } 4\end{array}$ & $\begin{array}{c}\text { Inducible endoribonuclease associated with antiviral response } \\
\text { mRNA, Messenger RNA; NSD, nonstop decay; NMD, nonsense-mediated decay; GMD, glucocorticoid receptor-mediated }\end{array}$
\end{tabular}
decay.

recruited to RNA substrates by a variety of RNAbinding proteins (RBPs) and complexes (e.g., Du et al. 2016; Stowell et al. 2016; Yamaji et al. 2017), including the translation initiation factor transporter 4E-T (Nishimura et al. 2015). There are two enzymatic complexes that carry out the majority of cytoplasmic deadenylation in eukaryotes (Wahle and Winkler 2013). The poly(A) nuclease (PAN) PAN2/PAN3 complex is thought to be responsible for preliminary poly(A) trimming (Wolf and Passmore 2014). PAN2 functions as the catalytically active subunit, whereas PAN3 is critical in recruitment of PAN2 to the $\operatorname{poly}(\mathrm{A})$ tail and efficient poly(A) tail shortening (Jonas et al. 2014; Schäfer et al. 2014; Wolf et al.2014). There are two isoforms of PAN3 (3S and 3L) that can, respectively, activate or repress PAN2 deadenylation activity (Chen et al. 2017). Subsequently, the bulk of deadenylation is performed by the CCR4-NOT complex (Collart and Panasenko 2017). While several proteins comprise this complex, the three key proteins appear to be NOT1, CCR4 (CNOT6), and CAF1/POP2 (CNOT7). NOT1 serves as the structural backbone of the complex (Basquin et al. 2012), whereas CCR4 and CAF1/POP2 are the catalytically active deadenylases (Maryati et al. 2015). Recent evidence suggests that CCR4 and CAF1/POP2 deadenylases can also remove terminal non-adenosine residues if the complex is anchored to the RNA substrate by upstream adenosine tracts (Niinuma et al. 2016). Finally, in addition to PAN2/PAN3 and CCR4-NOT, eukaryotic cells also contain a number of addi- tional deadenylases that can influence poly(A) tail length (Skeparnias et al. 2017) and play roles in small RNA biogenesis. Of these, poly(A) ribonuclease (PARN), the most extensively studied, can interact with the $5^{\prime}$ cap of the mRNA substrate to enhance enzymatic activity/processivity (Virtanen et al. 2013; Niedzwiecka et al. 2016). Interestingly, mutations in PARN are associated with human diseases, including dyskeratosis congenita, bone marrow failure, and hypomyelination (Dhanraj et al. 2015; Mason and Bessler 2015). Additionally, ANGEL1, ANGEL2, and the circadian rhythm-associated Nocturnin enzyme are distant homologs of CCR4 that are thought to target specific mRNAs for poly(A) tail shortening (Kojima et al. 2015).

Step Two: Decapping/Removal of the $5^{\prime 7 \mathrm{~m}} \mathrm{Gppp}$ Modification to Generate a 5'Monophosphate

In addition to a key role in promoting translation initiation, the 7-methylguanosine $\left(\mathrm{m}^{7} \mathrm{G}\right)$ cap on mRNAs also serves to protect transcripts from highly active $5^{\prime}$ to $3^{\prime}$ exoribonucleases that are present in both the nucleus and cytoplasm of eukaryotic cells (Jones et al. 2012). Thus, the process of decapping is a crucial step in the decay of many mRNAs, and can be either deadenylation-dependent or, in certain cases, deadenylation-independent when decay is initiated by alternative mechanisms that do not involve the poly $(\mathrm{A})$ tail as outlined below. The majority of decapping activity is thought to be 
provided by DCP2, but recent work has identified seven additional NUDIX proteins (e.g., NUDT3 and NUDT16) as well as DXO proteins that act on distinct RNA subsets (Grudzien-Nogalska and Kiledjian 2017) and alternative cap structures (Jiao et al. 2017). In addition to sequence context, reversible methylation of the adenosine adjacent to the cap can have a large influence on decapping rates and overall mRNA stability (Mauer et al. 2017). The well-characterized DCP2 enzyme requires several additional cofactors in vivo to effectively access mRNA substrates as well as attain an optimally active enzymatic conformation (Wurm et al. 2017). Thus, there is a rather elaborate orchestration involved in DCP2 RNA targeting/activation. Decapping cofactors include DCP1, the Lsm1-7 complex, PATL1 (Pat1), DDX6 (Dhh1), LSM14 (Scd6), and a set of EDC proteins. The DCP2/DCP1 complex (Valkov et al. 2017) catalyzes hydrolysis of the cap structure, but generally interacts with mRNA caps with only weak affinity (Ziemniak et al. 2016). The Lsm1-7 complex (Wilusz and Wilusz 2013) associates with the deadenylated transcript and interacts with PATL1 to promote DCP1/2 recruitment (Chowdhury et al. 2014). The Lsm1-7-PAT1 complex can also be usurped by viruses to promote translation (Jungfleisch et al. 2015). EDC1, 2, and 3 proteins, as well as the related LSM14/Scd6 protein, serve as a scaffold for assembly and activation of DCP $1 / 2$ enzyme (Fromm et al. 2012; Charenton et al. 2016). The RNA helicase DDX6 (Dhh1) is an evolutionarily conserved factor that interacts with other decapping activators and likely remodels the transcript for efficient complex assembly (Sharif et al. 2013). Finally, in addition to this multifaceted set of factors involved in direct interaction of the decapping complex with RNAs, numerous RBPs as well as terminal RNA modifications also play key roles in the initial identification of mRNAs targeted for decapping. Terminal uridylation of an mRNA or RNA fragment, for example, can effectively trigger/stimulate decapping (Song and Kiledjian 2007; Rissland and Norbury 2009). Finally, the $7 \mathrm{kDa}$ microprotein NoBody has recently been reported to associate with the decapping complex and correlates well with mRNA decay processes
(D'Lima et al. 2016). Therefore, in addition to conventional protein factors, small polypeptides also appear to play a role in the assembly and function of the decapping complex.

Step Three (Option 1): $5^{\prime}$ to $3^{\prime}$

Exoribonucleolytic Decay in the Cytoplasm

$\mathrm{XRN} 1$ is the primary $5^{\prime}$ to $3^{\prime}$ cytoplasmic exonuclease and is well conserved throughout eukaryotes (Jones et al. 2012). XRN1 preferentially degrades RNAs with a $5^{\prime}$ monophosphate endprecisely corresponding to the $5^{\prime}$ termini left following mRNA decapping or most endonucleolytic RNA cleavages. XRN1 is a highly processive enzyme that generally can only be stalled by rather elaborate RNA structures, for example, three helix junction knot-like structures found in flavivirus RNAs (Chapman et al. 2014). Interestingly, there is growing evidence that XRN1 plays a key role in overall RNA decay and homeostasis of gene expression (Chavèz et al. 2016). Repression of XRN1 by stalling on flavivirus structures results in a concomitant repression of decapping and deadenylation in the infected cell (Moon et al. 2012, 2015). In addition, buffering effects between mRNA transcription and degradation rates appear to be mediated by XRN1 in some fashion (Haimovich et al. 2013; Sun et al. 2013).

Step Three (Option 2): $3^{\prime}$ to $5^{\prime}$ Exonucleolytic Decay in the Cytoplasm

$3^{\prime}$ to $5^{\prime}$ decay in the cytoplasm is performed primarily by a multiunit complex called the exosome (Zinder and Lima 2017). The core of the exosome (Exo9) consists of nine protein subunits that are highly conserved throughout eukaryotes, but nucleolytically inactive. Exo9 binds to the catalytically active subunit RRP44 to form the active exosome (Exo10) (Kowalinski et al. 2016; Zinder et al. 2016). Deadenylation generates an unprotected $3^{\prime}$ end of an mRNA, which the exosome can interact with to initiate $3^{\prime}$ to $5^{\prime}$ decay. The exosome is capable of performing specific functions based on association with different cofactors. For example, the GTPbinding protein SKI7 (Kowalinski et al. 2015) 
recruits the exosome to mRNAs with abnormal translation termination, thereby enabling nonstop decay (NSD) (Graille and Séraphin 2012). Furthermore, the RNA-induced silencing complex (RISC) recruits the exosome to degrade the $5^{\prime}$ product of Ago2-mediated cleavages (Orban and Izaurralde 2005). Following $3^{\prime}$ to $5^{\prime}$ decay, the $\mathrm{m}^{7} \mathrm{G}$ cap is removed from the remaining short oligonucleotide by the scavenger decapping enzyme DCPS (Liu et al. 2008) along with FHIT/Aph1 (Taverniti and Seraphin 2015). From a biological perspective, DCPS mutations have been associated with human neurological diseases (Ng et al. 2015) and DCPS inhibitors are being developed as potential therapeutics for spinal muscular atrophy (Gopalsamy et al. 2017). DCPS has also been implicated in microRNA (miRNA) turnover (Bosse et al. 2013), further illustrating the overall importance of this enzyme and impact on multiple pathways in cell biology.

In addition to the exosome, $3^{\prime}$ to $5^{\prime}$ decay of coding and noncoding RNAs can be accomplished by DIS3L2 (Łabno et al. 2016; Pirouz et al. 2016; Ustianenko et al. 2016). DIS3L2 preferentially recognizes mRNAs with short poly $(\mathrm{U})$-tracts at their $3^{\prime}$ end that are added by poly(U) polymerases (PUPs) like TUT4/7 (Viegas et al. 2015). Intriguingly, DIS3L2 has been linked to apoptosis (Thomas et al. 2015), and mutations in DIS3L2 are associated with Perlman syndrome (Pashler et al. 2016). These observations further underscore the biological and developmental importance of this $3^{\prime}$-to- $5^{\prime}$ exoribonuclease.

\section{An Alternative Way to Create Exoribonuclease-Sensitive mRNAs: Endonucleolytic Decay}

The generation of an accessible $5^{\prime}$ monophosphate or $3^{\prime}$ hydroxyl for an exoribonuclease is the key step in turnover of the body of the mRNA (Fig. 1). In addition to deadenylation and decapping, an appreciation of the extent that endoribonucleases contribute to general mRNA decay has significantly increased over the years. In addition to the well-characterized cleavage events that occur during miRNA and small-in- terfering RNA (siRNA)-mediated RNA interference (RNAi) (Park and Shin 2014), there are numerous other endoribonucleases that target and cleave mRNAs in a regulated fashion for subsequent exonucleolytic decay. Because endoribonuclease activity significantly modulates the fate of an mRNA, these enzymes are tightly regulated. In fact, cells contain a cysteine-rich ribonuclease inhibitor (RNH1) to protect them from the plethora of unwanted RNase A type ribonucleases secreted by cells in their environment (Thomas et al. 2016). Four of the major endoribonucleases that play significant roles in the regulation of mRNA stability in mammalian cells are highlighted below.

MCPIP1/Regnase 1 is a CCCH zinc fingercontaining protein that plays a major role in regulating cellular mRNA decay, including transcripts encoding components of the immune system (Uehata and Takeuchi 2017), iron homeostasis (Yoshinaga et al. 2017), and body fat accumulation (Habacher et al. 2016). Regnase 1 knockout mice develop anemia, severe systemic inflammation, and produce high amounts of autoantibodies. In terms of immune regulation, a key mRNA target of Regnase 1 appears to be the cytokine interleukin (IL)-6 (Uehata and Takeuchi 2017). Regnase 1 activity is regulated by phosphorylation, particularly through IкB kinases in response to immune stimulation (Iwasaki et al. 2011).

The endoribonuclease HRSP12 plays a major role in the formation and activity of the protein complex that mediates glucocorticoid receptor-mediated decay (GMD), a recently described decay pathway that plays a wide role in cell biology (Park et al. 2016). Although it is well known to be a DNA-binding transcription factor, glucocorticoid receptor also binds in a sequence-selective fashion to RNA and recruits PNCR2 and UPF1 to target the transcript for decay (Cho et al. 2015).

Finally, recent work has expanded the biological impact of two well-studied endoribonucleases, IRE-1 and RNase L. In addition to its contributions to endoplasmic reticulum stress and the unfolded protein response (Moore and Hollien 2015), IRE-1 selectively targets a series of mRNAs and plays a key role in a variety of 
A.M. Heck and J. Wilusz

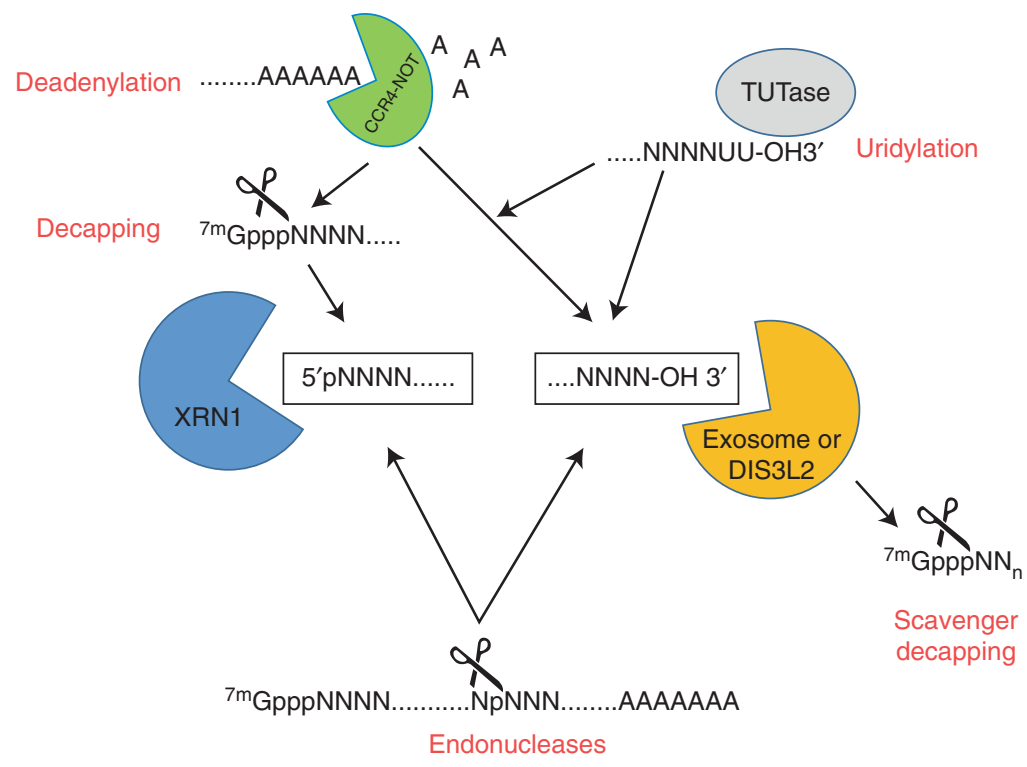

Figure 1. The multiple pathways for exonucleases to gain access to RNAs targeted for degradation. $5^{\prime}-3^{\prime}$ exoribonucleases (XRN1) require a $5^{\prime}$ monophosphate, whereas $3^{\prime}-5^{\prime}$ exoribonucleases (exosome and DIS3L2) require an accessible $3^{\prime}$ hydroxyl. A $5^{\prime}$ monophosphate can be generated in a regulated fashion by the process of decapping, which can be deadenylation ( poly $(\mathrm{A})$ tail shortening) dependent or deadenylation independent. Deadenylation itself generates an accessible $3^{\prime}$ hydroxyl for exoribonucleases. Poly(U) polymerases (also called TUTases) can uridylate the $3^{\prime}$ end of RNA targets to increase DIS3L2 exonuclease accessibility. In the $3^{\prime}-5^{\prime}$ exonuclease pathway, the scavenger decapping enzyme DCPS acts on short capped oligonucleotides to promote full degradation. Finally, rather than remodeling the natural $5^{\prime}$ and $3^{\prime}$ ends of the target mRNA, endoribonucleases, including the RNA-induced silencing complex (RISC) complex of the RNA interference (RNAi) pathway, can cleave a transcript internally and generate fragments with $5^{\prime}$ monophosphate and $3^{\prime}$ hydroxyl ends for exonucleolytic decay.

systems, including dendritic cell biology, glucose-responsive insulin secretion, and energy regulation in obesity (Eletto et al. 2016; Shan et al. 2017; Tavernier et al. 2017). RNase L, an inducible endoribonuclease known best for its role in antiviral responses (Cooper et al. 2015), also selectively targets cellular mRNAs to influence overall gene expression (Brennan-Laun et al. 2014; Rath et al. 2015).

\section{INTERPLAY BETWEEN THE TRANSLATIONAL AND RNA DECAY MACHINERIES}

Introduction/Evidence for Co-Translational Decay

The definitive function of an mRNA is to produce protein through translation. Building on the advances made over the last two decades in characterizing the pathways of mRNA decay, a full mechanistic understanding of how mRNA turnover is regulated and integrated into overall gene expression is one of the next milestones in the field. Given the extensive networking that occurs between many processes in RNA biology, it is not surprising that the process of translation is intertwined in several ways with RNA decay. Thus, in this section, we focus on co-translational mRNA decay (Fig. 2) and its impact on gene expression.

Numerous early observations suggest that the translation of an mRNA can affect its degradation rate in mammalian cells. Pioneering work in the 1980s and early 1990s on a variety of oncogene-encoding mRNAs, including cmyc (Dani et al. 1984; Linial et al. 1985; LairdOffringa et al. 1990), c-fos (Rahmsdorf et al. 1987), jun (Ryseck et al. 1988), and myb 
RNA Decay and Translation

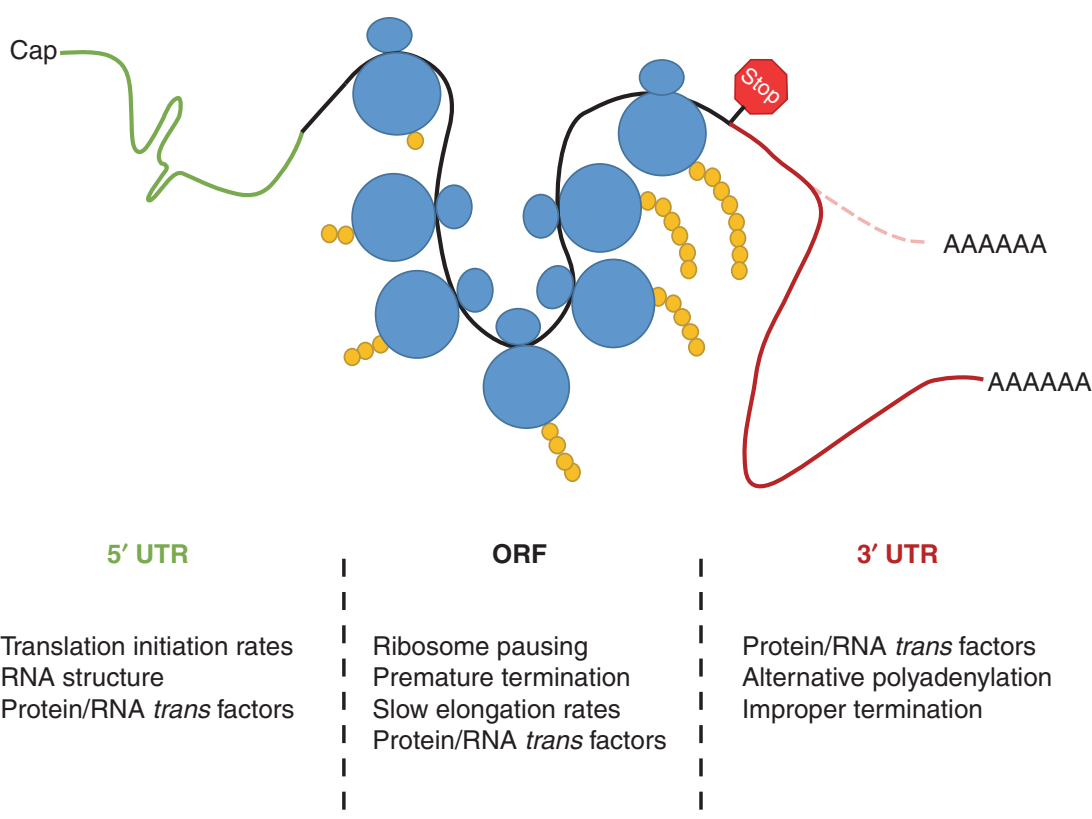

Figure 2. Numerous regulatory points exist throughout the transcript to modulate co-translational messenger RNA (mRNA) decay. A brief overview of the factors and the location on the transcript that can influence the rate of mRNA decay in association with ribosome loading, elongation, and termination. In the $5^{\prime}$ untranslated region (UTR) (green), RNA structure, initiation rates, and RNA-binding protein (RBP)/RNA factors acting in trans can co-regulate mRNA decay and translation. As ribosomes (blue) read through the open reading frame (ORF) (black), elongation speed or lack thereof (ribosome pausing) is the primary feature that links active translation and mRNA decay. Events such as premature termination, RNA modification, or protein/RNA trans factor interaction can alter ribosomal speed, thus influencing mRNA stability. Finally, the $3^{\prime}$ UTR (red) can modulate mRNA decay and translation via interactions with other protein/RNA factors, different $3^{\prime}$ UTR isoforms that can arise by alternative polyadenylation (APA), or via improper termination, which can result from a defective ribosome or lack of a stop codon. The cell uses all of these regulatory mechanisms to ensure that accurate and efficient translation is achieved.

(Thompson et al. 1986), indicated that blocking translation, using small molecule drugs or the insertion of stem-loop structures in the $5^{\prime}$ untranslated region (UTR) to stop ribosome scanning, resulted in stabilization of these normally very short-lived mRNAs. The phenomenon was not limited to oncogene-related transcripts, as mRNAs encoding growth factors (Aharon and Schneider 1993), histones (Stimac et al. 1983), enzymes (Altus and Nagamine 1991), and receptors (Koeller et al. 1991) could also be stabilized by translational repression. In fact, an early global analysis using differential phage plaque hybridization extended the connection between mRNA translation and stability by identifying $>80$ mRNAs whose stability was influenced by translational repression (Almendral et al. 1988).
The changes in mRNA stability observed using global translational inhibitors such as cycloheximide, puromycin, or pactamycin must be interpreted with some caution, because a portion of the effects could be the result of indirect or "trans" effects. It is, however, abundantly clear that translation can directly influence the stability of an mRNA. A variety of observations support this contention, including the use of transcript-directed stem-loop structures in mRNAs (Aharon and Schneider 1993), the association of the context of the start codon with stability of the yeast PGK1 mRNA (LaGrandeur and Parker 1999), as well as the extensive literature on premature stop codons influencing transcript stability via nonsense-mediated decay (NMD) (Celik et al. 2017b; Karousis and Mühlemann 2017). In 
addition, extensive ribosome pausing (e.g., nogo decay [NGD] [Simms et al. 2017]) and incorrect ribosome termination (i.e., NSD [Klauer and van Hoof 2012]) also make a substantial contribution to the stability of an mRNA. There is also an inherent complexity between the interface of active translation and mRNA stability. A good example of this is the observation that the placement of a premature termination codon close to the AUG initiation site fails to elicit NMD, a phenomenon referred to as the AUG proximity effect (Pereira et al. 2015).

There is a growing body of evidence that supports the contention that a large portion of mRNA decay occurs co-translationally. For example, the decapping step of the major $5^{\prime}-3^{\prime}$ decay pathway in yeast has been shown to take place directly on polysomes ( $\mathrm{Hu}$ et al. 2009, 2010). In addition, altering growth conditions can cause the decapping activators DHH1 and PAT1 to relocalize to polysomes and target mRNAs for degradation (Drummond et al. 2011). The DHH1 RNA helicase has also been shown to slow ribosome movement and trigger mRNA decapping (Sweet et al. 2012). Finally, viral endonucleases can also be directly recruited to translating mRNAs and target them for degradation (Covarrubias et al. 2011).

Co-translational mRNA decay has also been shown to have practical applications. It is problematic to definitively assess ribosome movement/dynamics in living cells because of concerns about changes that can occur during requisite in vitro processing steps. By sequencing $5^{\prime}$ monophosphorylated decay intermediates, Steinmetz and colleagues have used cotranslational mRNA decay as a readout for the dynamics of ribosomal movement on mRNAs in a variety of yeast systems (Pelechano et al. 2015, 2016). The mRNA decay intermediates showed a three-nucleotide pattern of periodicity, consistent with the co-translational decay model in which XRN1 follows the last translating ribosome on an mRNA.

Biases in codon usage are clear in all organisms, but the impact of codon choice on the rate of translation elongation and associated mRNA stability was not fully clear. This was because of conflicting data from ribosome profiling studies and an associated surprising lack of sensitivity because of a variety of technical biases that can influence data interpretation ( $\mathrm{Yu}$ et al. 2015). Using cell-free translation assays, Liu and colleagues recently showed a clear association between codon preference and elongation rates $(\mathrm{Yu}$ et al. 2015). The elongation rate of ribosomes along an mRNA clearly influences the stability of the associated transcript via the DEAD-box protein Dhh1, which serves as a sensor for ribosome velocity as well as recruiting the mRNA decay machinery (Radhakrishnan et al. 2016). The impact of codon optimality on mRNA stability was revealed by demonstrating that substitution of optimal codons with synonymous but suboptimal ones impacts the rate of ribosome elongation and causes mRNA destabilization (Presnyak et al. 2015). This observation appears to be universal, as codon optimality has been shown to influence RNA decay in Escherichia coli (Boel et al. 2016) and ribosome pausing on a transcript also results in increased rates of mRNA decay in plants (Merret et al. 2015). In eukaryotes, the DEAD-box protein DDX6 (which is known as Dhhl in yeast) appears to be a sensor for ribosome speed and connects translation elongation rates to RNA decay (Radhakrishnan et al. 2016). DDX6/Dhh1 can both interact with the ribosome as well as interact with and regulate mRNA deadenylation and decapping factors (Coller et al. 2001), making it an attractive candidate for a factor that can couple slow ribosome progression with enhanced mRNA decay.

Multiple facets associated with the translation of an mRNA can influence its decay rate (Neymotin et al. 2016). The following sections will provide examples of how different parts of an mRNA, the $5^{\prime}$ UTR, the open reading frame (ORF), and the $3^{\prime}$ UTR can influence cotranslational mRNA decay.

\section{Examples of 5' UTR Impacts on Both} Translation and RNA Decay

\section{Hepatitis C Virus}

Internal ribosome entry sites (IRESs), commonly found in viral RNAs but also present in some eukaryotic transcripts (Weingarten-Gabbay et 
al. 2016), are highly structured regions in the $5^{\prime}$ UTR that promote translation initiation in a cap-independent fashion (Dai et al. 2015). The $5^{\prime}$ UTR of hepatitis C virus (HCV), which contains a well-characterized IRES (Khawaja et al. 2015), is thought to also hijack aspects of the cellular RNAi machinery to stabilize its own RNA and increase translation of viral products. microRNA-122 (miR-122) is highly abundant in the liver (Chang et al. 2004), the target tissue of HCV. Binding of the seed sequence and additional nucleotides at the $3^{\prime}$ end of miR-122 to multiple regions in the $5^{\prime}$ terminus of the $\mathrm{HCV}$ genome, just upstream of the IRES, stimulates HCV translation (Roberts et al. 2011; Wilson et al. 2011) and enhances RNA stability (Shimakami et al. 2012). Furthermore, it is the association with the miR-122 RISC complex, and not simply double-stranded RNA (dsRNA) formation between the miRNA and the HCV RNA that results in HCV RNA accumulation (Zhang et al. 2012). These studies, coupled with the discovery that the HCV 5' UTR is capable of stalling XRN1 (Moon et al. 2015), led to a model where HCV RNA recruits the miRISC complex, through interactions with miR-122 just upstream of the IRES, to act as a barrier against XRN1 accessing the naturally uncapped HCV RNA. This enhanced RNA stability enables accumulation of HCV RNA and increased viral translation. The usurping of the miRNA machinery by the $5^{\prime}$ UTR has recently been generalized to another member of Flaviviviridae, bovine viral diarrhea virus (BVDV) and its interaction with miR-17 (Scheel et al. 2016).

\section{Protein-RNA Interactions with the $5^{\prime}$ UTR that} Play Dual Roles in Stability and Translation

RBPs are one of the key factors involved in posttranscriptional gene regulation. RBP interactions with the $5^{\prime}$ UTR of target mRNAs can alter RNA degradation kinetics as well as affect translation by interfacing with initiation factors. HuR and AUF1 are well-studied RBPs that are classically known to regulate RNA decay through AUrich elements. HuR is strongly associated with mRNA stabilization, whereas AUF1 is typically associated with mRNA destabilization (Gram- matikakis et al. 2017; White et al. 2017). HuR and AUF1, along with the RISC component Ago2, have been implicated in regulating translation of a viral IRES element. HuR and Ago2 binding promotes translational activity of the enterovirus 71 IRES, whereas AUF1 binding represses it (Lin et al. 2015). Similarly, HuR enhances IRES-mediated translation of the X chromosome-linked inhibitor of apoptosis (XIAP) (Durie et al. 2011), whereas Ago2 associated with miR-10a promotes translation of ribosomal protein mRNAs (Ørom et al. 2008). Conversely, $\mathrm{HuR}$ can repress IRES-mediated translation of several transcripts (Kullmann et al. 2002; Meng et al. 2005; Yeh et al. 2008). Although the precise mechanism remains uncharacterized, it is postulated that HuR may block assembly of the IRES-associated ribosome-IRES interacting factor (ITAF) complex or impede the complex from initiating translation. Moreover, HuR significantly delays cap-dependent scanning by the $43 \mathrm{~S}$ preinitiation complex (Meng et al. 2005), resulting in repressed translation and increased degradation of the target mRNA. These studies, along with others in the field, show the complexity associated with RBP-mediated translation/ mRNA decay co-regulation, and add support to the notion that RBP-mRNA interactions cannot be defined by a simplistic linear model.

\section{DDX6-A Key Developmental Regulator of Translation and RNA Decay}

DDX6 is a member of the DEAD-box family of helicases that is well conserved throughout eukaryotes and has been implicated in mRNA translation and decay (Ostareck et al. 2014), including miRNA-mediated translational silencing (Kuzuoğlu-Öztürk et al. 2016). DDX6 interacts with the CNOT1 component of the CCR4NOT complex, which interacts with TNRC6/ GW182 (Chen et al. 2014; Rouya et al. 2014). An interaction between DDX6 and 4E-transporter (4E-T) (which interacts with eIF4E), in coordination with the CCR4-NOT complex, mediates miRNA-dependent translational repression (Ozgur et al. 2015; Kamenska et al. 2016). 4E-T has also been implicated in physically linking the two termini of mRNAs targeted 
for decay via interactions with eIF4E at the $5^{\prime}$ cap and the CCR4-NOT deadenylase complex at the $3^{\prime}$ end (Nishimura et al. 2015). The biological relevance of DDX6 coordinating co-translational decay has recently been shown by the ability of progenitor stem cells to modulate stem cell maintenance and differentiation. DDX6 was shown to be up-regulated during neuronal differentiation, and it interacts with the neuronal cell-fate determinant protein TRIM32 to stimulate activity of the miRNA Let-7a (Nicklas et al. 2015), which has previously been shown to help induce neuronal differentiation (Schwamborn et al. 2009). Conversely, in epidermal progenitor cells, DDX6 is believed to control a gene expression profile that inhibits differentiation while maintaining proliferation. Premature differentiation is prevented by destabilizing KLF4 mRNA through interactions with the $5^{\prime}$ UTR, whereas DDX6 forms a complex with YBX1 and eIF4E to promote translation of several self-renewal and proliferation transcripts (Wang et al. 2015). DDX6 is also used/usurped in a variety of ways by viruses (Ostareck et al. 2014), making it an interesting multifunctional protein regulator/ organizer in the cytoplasm. This further shows the impressive networking in post-transcriptional gene regulation.

\section{Examples of ORF-Associated Impacts on mRNA Stability}

\section{Codon Optimality/Translational Velocity and RNA Decay}

Whereas the effect of codon optimality and mRNA stability was described in the introduction to this section, it is useful to emphasize several aspects. First, the impact of codon optimality on translational speed and mRNA decay rates appears to be a conserved phenomenon. In addition to fungi and plants, higher eukaryotes also show a connection between the use of optimal codons and RNA decay, including zebrafish, Xenopus, mammals, and Drosophila (Bazzini et al. 2016; Chen and Coller 2016; Mishima and Tomari 2016; Zhao et al. 2017). Second, the DHH1 factor, which has previously been shown to slow ribosome movement to enhance cotranslational decapping (Sweet et al. 2012), has emerged as a key factor in monitoring codon optimality of mRNAs in yeast (Radhakrishnan et al. 2016). Next, even NMD rates can be influenced by codon selection (Celik et al. 2017a). This observation clearly shows the connection between the quality control of gene expression and ribosome elongation. Finally, recent global analyses have suggested that both codon optimality and properties of adjacent codons contribute to influence mRNA decay rates, indicating that pairs or perhaps strings of suboptimal codons can differentially regulate mRNA turnover (Harigaya and Parker 2017).

\section{No-Go Decay}

NGD is one of several quality-control mechanisms eukaryotic cells use to recognize and eliminate defective mRNAs during the translation process. Specifically, the NGD machinery releases ribosomes in a prolonged elongation stall by targeting the mRNA for endonucleolytic cleavage and subsequent canonical mRNA decay (Simms et al. 2017). Surveillance mechanisms like NGD are critical because the aberrant mRNA transcripts remove ribosomes from the translating pool, which places a significant burden on the cell. Dom34 and Hbs1 are the primary components that make up the NGD machinery (Passos et al. 2009; Chen et al. 2010). The Dom34/Hbs1 complex, in conjunction with $A B C E 1$, promotes ribosome dissociation and nascent peptide transfer RNA (tRNA) drop off (Shoemaker et al. 2010; Pisareva et al. 2011). While it has been reported that NGD results in the endonucleolytic cleavage of the aberrant mRNA (Doma and Parker 2006; Tsuboi et al. 2012), the enzyme(s) that performs the cleavage remains elusive. Reported causes of ribosome stalling that initiate NGD include structured RNA (e.g., stem loops [Doma and Parker 2006]), tracts of positively charged amino acids (Dimitrova et al. 2009), and defective ribosomes (Cole et al. 2009). Although NGD is generally considered a surveillance mechanism for aberrant translation, there are observations of natural NGD having a biological function in Drosophila (Xi et al. 2005; Passos et al. 2009) and Arabidopsis (Onouchi et al. 2005), suggesting 
that cells may use NGD to regulate gene expression in certain scenarios.

\section{The Exon Junction Complex (EJC) and Its Impact on General Translation/RNA Stability}

The EJC has been intimately associated with mRNA quality control and NMD (Woodward et al. 2017). An excellent source for more information on mRNA quality control and NMD can be found in Karousis and Mühlemann (2017). However, the function of this nuclear-initiated mRNA mark is broad, and it includes an impact on translation and conventional mRNA decay. The core EJC protein MLN51 can bind to eIF3 and promote translation of mRNAs (Chazal et al. 2013). However, additional core EJC proteins also appear to influence translation, including PYM (Diem et al. 2007) and Y14 (Lee et al. 2009). Curiously, the Y14 component of the EJC has been suggested to bind the mRNA $5^{\prime}$ cap as well as the primary decapping enzyme DCP2 through different domains (Chuang et al. 2013). Mutating Y14 so that it cannot bind the cap abrogates its ability to support translation, but does not impede the degradation of target mRNAs (Chuang et al. 2016). This nicely illustrates the interplay of the EJC with cytoplasmic post-transcriptional processes in determining the propensity of the mRNA to be translated as well as degraded.

Examples of 3' UTR Impacts on Both Translation and RNA Decay

Alternative $3^{\prime}$ UTRs and Combinatorial Actions of RBPS on 3' UTR Elements that Co-Regulate Decay/Translation

It is widely accepted that the $3^{\prime}$ UTRs of eukaryotic mRNAs contain a large proportion of the regulatory elements and binding motifs used by cells to regulate post-transcriptional gene expression. So it is logical to think that an additional mode of regulation that cells can use is to generate transcript isoforms with different $3^{\prime}$ UTRs (Bava et al. 2013). This process is termed alternative cleavage and polyadenylation or alternative polyadenylation (APA) and can have profound effects on mRNA translation efficien- cy and decay (Mayr 2016; Tian and Manley 2017). In a simplified model, shortening of the $3^{\prime}$ UTR induced by APA sites can alter RNA structure or eliminate miRNA or RBP-binding sites, which positively or negatively affect mRNA stability and translation. As miRNAmediated regulation is explained in detail in Fabian (2017), we will touch on a few notable RBPs that co-regulate decay and translation via interactions with the $3^{\prime}$ UTR. As mentioned previously, HuR is a widely studied RBP that promotes both mRNA stabilization as well as translation by preventing the interaction of repressive factors with the mRNA via competition for common binding regions (Lal et al. 2004; Kim et al. 2015; Liu et al. 2015; Blackinton and Keene 2016; Bose et al. 2016; Zhang et al. 2017). However, several studies have also implicated $\mathrm{HuR}$ in destabilization of transcripts through recruitment of other RBPs (Chang et al. 2010) and the miRISC complex (Kim et al. 2009). Similar to HuR, the Pumilio or PUF family of proteins is present in all eukaryotes (Zamore et al. 1997) and modulates mRNA fate through $3^{\prime}$ UTR interactions (Morris et al. 2008; Hafner et al. 2010). PUF proteins are potent repressors that can accelerate deadenylation (Weidmann et al. 2014) through interactions with POP2 (Goldstrohm et al. 2006) and inhibit translation by blocking polypeptide elongation (Friend et al. 2012). PUF proteins play a regulatory role in a wide variety of biological functions, including development (Datla et al. 2014; Mak et al. 2016), cell proliferation (Naudin et al. 2017), stress response (Russo and Olivas 2015), and neurological processes (Sharifnia and Jin 2014; Gennarino et al. 2015; Arvola et al. 2017). Whereas HuR and the PUF family of proteins are two of the most prolific examples of how RBPs can interact with the $3^{\prime}$ UTR to influence mRNA translation and stability, there are numerous other $3^{\prime}$ UTR-binding RBPs the cell uses to regulate gene expression globally or on a subset of genes.

\section{Nonstop Decay}

Finally, NSD is generally considered a qualitycontrol mechanism that targets ribosomes 
A.M. Heck and J. Wilusz

stalled at the $3^{\prime}$ end of mRNAs, which is often caused by lack of a stop codon as a result of premature transcriptional termination and polyadenylation (Ito-Harashima et al. 2007; Simms et al. 2017). Similar to NGD discussed above, the potential loss of functional ribosomes because of build-up on aberrant mRNAs and subsequent impact on cell survival makes NSD a crucial surveillance mechanism. A premature polyadenylation event on a transcript results in ribosome stalling as it tries to decode the poly(A) tail into poly(Lys) residues. Consistent with this notion, poly(A) tracts within the ORF (Ito-Harashima et al. 2007; Kuroha et al. 2010) as well as electrostatic interactions between positively charged lysine residues and the negatively charged tunnel of the ribosome ( $\mathrm{Lu}$ and Deutsch 2008; Dimitrova et al. 2009) have been shown to elicit ribosome stalling. Several studies have implied the ribosome along with the GTPase SKI7 are responsible for the initial recognition of mRNAs with aberrantly placed poly(A) tracts (Araki et al. 2001; van Hoof et al. 2002; Akimitsu et al. 2007; Arthur et al. 2015; Garzia et al. 2017; Juszkiewicz and Hedge 2017). Whereas SKI7 is primarily associated with NSD, it is a paralog of the NGD factor HBS1, and SKI7 deletion strains in yeast are complemented by introducing HBS1 (van Hoof 2005). Furthermore, Dom34/Hbs1 has been linked to dissociation of ribosomes stalled in the $3^{\prime}$ UTR of mRNAs (Tsuboi et al. 2012; Saito et al. 2013), suggesting functional overlap of the SKI7 protein and Dom34/Hbs1 complex. Conversely, a recent study hypothesized a competitive mechanism of action between SKI7 and the Dom34/Hbs1 complex for interactions with ribosomes in NSD (Horikawa et al. 2016). This suggests that the relationship between these two elements is more complicated than originally thought and requires further studies.

\section{CONCLUDING REMARKS/FUTURE DIRECTIONS}

In summary, whereas the processes of translation and mRNA decay are naturally competing for the same parts of the mRNA, available evidence indicates that translation and general
mRNA decay are not independent processes, but are intricately networked. A variety of interesting questions remain to be answered. Although aspects of the $5^{\prime}-3^{\prime}$ decay pathway are linked to translational dynamics on the targeted mRNA, what about $3^{\prime}-5^{\prime}$ decay by the exosome and or DIS3L2? How complex is the interplay between the ribosome and the mRNA decay machinery in terms of protein-protein interactions and the range of cofactor requirements? Although ribosome elongation rates appear to influence mRNA decay, is the relationship mutual? In other words, does RNA decay influence ribosome dynamics on the targeted mRNA? Does the mechanism/route of translation initiation influence mRNA decay rates as well as the rate of elongation? Are changes in mRNA stability as a result of slower elongation rates through suboptimal codons also associated with the NGD pathway and Dom34/HBS1 complex, or do these stability changes simply reflect alterations in conventional mRNA decay pathways? How extensively are associations between translation and decay regulated at the developmental level, and are they perhaps dysregulated/disconnected in cancer cells to promote altered gene expression profiles and remove controls over cellular gene expression? Finally, from a pathogen perspective, how do arboviruses that flipflop between growth in insect vectors and vertebrate hosts deal with major differences in codon optimality between the two eukaryotic environments and maintain the stability of their RNA transcripts? Elucidating these and other aspects of the interplay between the fundamental translation apparatus and mRNA decay machinery should yield many interesting insights in the future.

\section{ACKNOWLEDGMENTS}

We thank members of the Wilusz laboratories for helpful discussions. A.M.H. is supported in part through the National Science Foundation Research Traineeship (NSF-NRT) award \#1450032 and an NSF Graduate Research Fellowship. RNA stability work in the Wilusz laboratory is supported by the National Institutes of Health (NIH) awards GM114217, AI123136, 
and AI130497, as well as a grant from the College of Veterinary Medicine and Biomedical Sciences (CVMBS) College Research Council to J.W.

\section{REFERENCES}

${ }^{*}$ Reference is also in this collection.

Aharon T, Schneider RJ. 1993. Selective destabilization of short-lived mRNAs with the granulocyte-macrophage colony-stimulating factor AU-rich $3^{\prime}$ noncoding region is mediated by a cotranslational mechanism. Mol Cell Biol 13: $1971-1980$.

Akimitsu N, Tanaka J, Pelletier J. 2007. Translation of nonSTOP mRNA is repressed post-initiation in mammalian cells. EMBO J 26: 2327-2338.

Almendral JM, Sommer D, Macdonald-Bravo H, Burckhardt J, Perera J, Bravo R. 1988. Complexity of the early genetic response to growth factors in mouse fibroblasts. Mol Cell Biol 8: 2140-2148.

Altus MS, Nagamine Y. 1991. Protein synthesis inhibition stabilizes urokinase-type plasminogen activator mRNA. Studies in vivo and in cell-free decay reactions. J Biol Chem 266: 21190-21196.

Araki Y, Takahashi S, Kobayashi T, Kajiho H, Hoshino S, Katada T. 2001. Ski7p G protein interacts with the exosome and the Ski complex for $3^{\prime}$-to- $5^{\prime}$ mRNA decay in yeast. EMBO J 20: 4684-4693.

Arthur L, Pavlovic-Djuranovic S, Smith-Koutmou K, Green R, Szczesny P, Djuranovic S. 2015. Translational control by lysine-encoding A-rich sequences. Sci Adv 1: e1500154.

Arvola RM, Weidmann CA, Tanaka Hall TM, Goldstrohm AC. 2017. Combinatorial control of messenger RNAs by Pumilio, Nanos and brain tumor proteins. RNA Biol doi: 10.1080/15476286.2017.1306168.

Atkinson GC, Baldauf SL, Hauryliuk V. 2008. Evolution of nonstop, no-go and nonsense-mediated mRNA decay and their termination factor-derived components. BMC Evol Biol 8: 290.

Basquin J, Roudko V, Rode M, Basquin C, Séraphin B, Conti E. 2012. Architecture of the nuclease module of the yeast Ccr4-Not complex: The Not1-Caf1-Ccr4 interaction. $\mathrm{Mol}$ Cell 48: 207-218.

Bava FA, Eliscovich C, Ferreira PG, Miñana B, Ben-Dov C, Guigó R, Valcárcel J, Méndez R. 2013. CPEB1 coordinates alternative $3^{\prime}$-UTR formation with translational regulation. Nature 495: 121-125.

Bazzini AA, del Viso F, Moreno-Mateos MA, Johnstone TG, Vejnar CE, Qin Y, Yao J, Khokha MK, Giraldez AJ. 2016. Codon identity regulates mRNA stability and translation efficiency during the maternal-to-zygotic transition. EMBO J 35: 2087-2103.

Blackinton JG, Keene JD. 2016. Functional coordination and HuR-mediated regulation of mRNA stability during T cell activation. Nucleic Acids Res 44: 426-436.

Boel G, Letso R, Neely H, Price WN, Wong KH, Su M, Luff JD, Valecha M, Everett JK, Acton TB, et al. 2016. Codon influence on protein expression in E. coli correlates with mRNA levels. Nature 529: 358-363.

Bose S, Tholanikunnel TE, Reuben A, Tholanikunnel BG, Spicer EK. 2016. Regulation of nucleolin expression by miR-194, miR-206, and HuR. Mol Cell Biochem 417: 141-153.

Bosse GD, Ruegger S, Ow MC, Vasquez-Rifo A, Rondeau EL, Ambros VR, Grobhans H, Simard MJ. 2013. The decapping scavenger enzyme DCS-1 controls microRNA levels in Caenorhabditis elegans. Mol Cell 50: 281-287.

Brennan-Laun SE, Li XL, Ezelle HJ, Venkataraman T, Blackshear PJ, Wilson GM, Hassel BA. 2014. RNase L attenuates mitogen-stimulated gene expression via transcriptional and post-transcriptional mechanisms to limit the proliferative response. J Biol Chem 289: 33629-33643.

Celik A, Baker R, He F, Jacobson A. 2017a. High-resolution profiling of NMD targets in yeast reveals translational fidelity as a basis for substrate selection. RNA 23: 735748.

Celik A, He F, Jacobson A. 2017b. NMD monitors translational fidelity 24/7. Curr Genet doi: 10.1007/s00294-0170709-4.

Chang J, Nicolas E, Marks D, Sander C, Lerro A, Buendia MA, Xu C, Mason WS, Moloshok T, Bort R, et al. 2004. miR-122, a mammalian liver-specific microRNA, is processed from hor mRNA and may downregulate the high affinity cationic amino acid transporter CAT-1. RNA Biol 1: 106-113.

Chang N, Yi J, Guo G, Liu X, Shang Y, Tong T, Cui Q, Zhan M, Gorospe M, Wang W. 2010. HuR uses AUF1 as a cofactor to promote p16INK4 mRNA decay. Mol Cell Biol 30: 3875-3886.

Chapman EG, Costantino DA, Rabe JL, Moon SL, Wilusz J, Nix JC, Kieft JS. 2014. the structural basis of pathogenic subgenomic flavivirus RNA (sfRNA) production. Science 344: 307-310.

Charenton C, Taverniti V, Gaudon-Plesse C, Back R, Seraphin B, Graille M. 2016. Structure of the active form of Dcp1-Dcp2 decapping enzyme bound to $\mathrm{m}^{7} \mathrm{GDP}$ and its Edc3 activator. Nat Struct Mol Biol 23: 982-986.

Chavèz S, Garcia-Martinez J, Delgado-Ramos L, Pèrez-Ortin JE. 2016. The importance of controlling mRNA turnover during cell proliferation. Curr Genet 62: 701-710.

Chazal PE, Daguenet E, Wendling C, Ulryck N, Tomasetto C, Sargueil B, Le Hir H. 2013. EJC core component MLN51 interacts with eIF3 and activates translation. Proc Natl Acad Sci 110: 5903-5908.

Chen Y, Coller J. 2016. A universal code for mRNA stability? Trends Genet 32: 687-688.

Chen C, Shyu A. 2017. Emerging themes in regulation of global mRNA turnover in cis. Trends Biochem Sci 42: 1627.

Chen L, Muhlrad D, Hauryliuk V, Cheng Z, Lim MK, Shyp V, Parker R, Song H. 2010. Structure of the Dom34/Hbs1 complex and implications for no-go decay. Nat Struct Mol Biol 17: 1233-1240.

Chen Y, Boland A, Kuzuoğlu-Öztürk D, Bawankar P, Loh B, Chang CT, Weichenrieder O, Izaurralde E. 2014. A DDX6-CNOT1 complex and W-binding pockets in CNOT9 reveal direct links between miRNA target recognition and silencing. Mol Cell 54: 737-750. 
A.M. Heck and J. Wilusz

Chen C, Zhang Y, Xiang Y, Han L, Shyu A. 2017. Antagonistic actions of two human Pan3 isoforms on global mRNA turnover. RNA doi: 10.1261/rna.061556.117.

Cho H, Park OH, Park J, Ryu I, Kim J, Ko J, Kim YK. 2015. Glucocorticoid receptor interacts with PNRC2 in a ligand-dependent manner to recruit UPF1 for rapid mRNA degradation. Proc Natl Acad Sci 112: 1540-1549.

Chowdhury A, Kalurupalle S, Tharun S. 2014. Pat1 contributes to the RNA binding activity of the Lsm1-7-Pat1 complex. RNA 20: 1465-1475.

Chuang TW, Chang WL, Lee KM, Tarn WY. 2013. The RNA-binding protein Y14 inhibits mRNA decapping and modulates processing body formation. Mol Biol Cell 24: $1-13$.

Chuang TW, Lee K, Lou Y, Lu C, Tarn WY. 2016. A point mutation in the exon junction complex factor Y14 disrupts its function in mRNA cap binding and translation enhancement. J Biol Chem 291: 8565-8574.

Cole SE, LaRiviere FJ, Merrikh CN, Moore MJ. 2009. A convergence of rRNA and mRNA quality control pathways revealed by mechanistic analysis of nonfunctional rRNA decay. Mol Cell 34: 440-450.

Collart MA, Panasenko OO. 2017. The Ccr4-Not complex: Architecture and structural insights. In Sub-cellular biochemistry, Vol. 83, pp. 349-379. Springer, New York.

Coller JM, Tucker M, Sheth U, Valencia-Sanchez MA, Parker R. 2001. The DEAD box helicase, Dhh1p, functions in mRNA decapping and interacts with both the decapping and deadenylase complexes. RNA 7: 1717-1727.

Cooper DA, Banerjee S, Chakrabarti A, García-Sastre A, Hesselberth JR, Silverman RH, Barton DJ. 2015. RNase $\mathrm{L}$ targets distinct sites in influenza A virus RNAs. J Virol 89: 2764-2776.

Covarrubias S, Gaglia MM, Kumar GR, Wong W, Jackson AO, Glaunsinger BA. 2011. Coordinated destruction of cellular messages in translation complexes by the $\gamma$ herpesvirus host shutoff factor and the mammalian exonuclease Xrn1. PLoS Pathog 7: e1002339.

Dai W, Ma W, Li Q, Tao Y, Ding P, Zhu R, Jin J. 2015. The 5' UTR of DDB2 harbors an IRES element and upregulates translation during stress conditions. Gene 573: 57-63.

Dani C, Blanchard JM, Piechaczyk M, El Sabouty S, Marty L, Jeanteur P. 1984. Extreme instability of myc mRNA in normal and transformed human cells. Proc Natl Acad Sci 81: 7046-7050.

Datla US, Scovill NC, Brokamp AJ, Kim E, Asch AS, Lee MH. 2014. Role of PUF-8/PUF protein in stem cell control, sperm-oocyte decision and cell fate reprogramming. $J$ Cell Physiol 229: 1306-1311.

Dhanraj S, Gunja SMR, Deveau AP, Nissbeck M, Boonyawat B, Coombs AJ, Renieri A, Mucciolo M, Marozza A, Buoni $S$, et al. 2015. Bone marrow failure and developmental delay caused by mutations in poly $(\mathrm{A})$-specific ribonuclease $(P A R N)$. J Med Genet 52: 738-748.

Diem MD, Chan CC, Younis I, Dreyfuss G. 2007. PYM binds the cytoplasmic exon-junction complex and ribosomes to enhance translation of spliced mRNAs. Nat Struct Mol Biol 14: 1173-1179.

Dimitrova LN, Kuroha K, Tatematsu T, Inada T. 2009. Nascent peptide-dependent translation arrest leads to
Not4p-mediated protein degradation by the proteasome. J Biol Chem 284: 10343-10352.

D’Lima NG, Ma J, Winkler L, Chu Q, Loh KH, Corpuz EO, Budnik BA, Lykke-Andersen J, Saghatelian A, Slavoff SA. 2016. A human microprotein that interacts with the mRNA decapping complex. Nat Chem Biol 13: 174-180.

Doma MK, Parker R. 2006. Endonucleolytic cleavage of eukaryotic mRNAs with stalls in translation elongation. $\mathrm{Na}$ ture 440: 561-564.

Drummond SP, Hildyard J, Firczuk H, Reamtong O, Li N, Kannambath S, Claydon AJ, Beynon RJ, Eyers CE, McCarthy JEG. 2011. Diauxic shift-dependent relocalization of decapping activators Dhh1 and Pat1 to polysomal complexes. Nucleic Acids Res 39: 7764-7774.

Du H, Zhao Y, He J, Zhang Y, Xi H, Liu M, Ma J, Wu L. 2016. YTHDF2 destabilizes m6A-containing RNA through direct recruitment of the CCR4/NOT deadenylase complex. Nat Commun 7: 1262-1266.

Durie D, Lewis SM, Liwak U, Kisilewicz M, Gorospe M, Holcik M. 2011. RNA-binding protein HuR mediates cytoprotection through stimulation of XIAP translation. Oncogene 30: 1460-1469.

Eletto D, Boyle S, Argon Y. 2016. PDIA6 regulates insulin secretion by selectively inhibiting the RIDD activity of IRE1. FASEB J 30: 653-665.

Ernoult-Lange M, Baconnais S, Harper M, Minshall N, Souquere S, Boudier T, Bénard M, Andrey P, Pierron G, Kress $M$, et al. 2012. Multiple binding of repressed mRNAs by the P-body protein Rck/p54. RNA 18: 1702-1715.

* Fabian M. 2017. microRNAs. Cold Spring Harb Perspect Biol doi: 10.1101/cshperspect.a032771.

Friend K, Campbell ZT, Cooke A, Kroll-Conner P, Wickens MP, Kimble J. 2012. A conserved PUF-Ago-eEF1A complex attenuates translation elongation. Nat Struct Mol Biol 19: $176-183$.

Fromm SA, Truffault V, Kamenz J, Braun JE, Hoffmann NA, Izaurralde E, Sprangers R. 2012. The structural basis of Edc3- and Scd6-mediated activation of the Dcp1:Dcp2 mRNA decapping complex. EMBO J 31: 279-290.

Garzia A, Jafarnejad SM, Meyer C, Chapat C, Gogakos T, Morozov P, Amiri M, Shapiro M, Molina H, Tuschl T, et al. 2017. The E3 ubiquitin ligase and RNA-binding protein ZNF598 orchestrates ribosome quality control of premature polyadenylated mRNAs. Nat Commun 8: 16056.

Gennarino V, Singh RK, White JJ, De Maio A, Han K, Kim JY, Jafar-Nejad P, di Ronza A, Kang H, Sayegh LS, et al. 2015. Pumilio1 Haploinsufficiency leads to SCA1-like neurodegeneration by increasing wild-type Ataxin1 levels. Cell 160: 1087-1098.

Goldstrohm AC, Hook BA, Seay DJ, Wickens M. 2006. PUF proteins bind Pop2p to regulate messenger RNAs. Nat Struct Mol Biol 13: 533-539.

Gopalsamy A, Narayanan A, Liu S, Parikh MD, Kyne RE, Fadeyi O, Tones MA, Cherry JJ, Nabhan JF, LaRosa G, et al. 2017. Design of potent mRNA decapping scavenger enzyme (DcpS) inhibitors with improved physicochemical properties to investigate the mechanism of therapeutic benefit in spinal muscular atrophy (SMA). J Med Chem 60: 3094-3108. 
Graille M, Séraphin B. 2012. Surveillance pathways rescuing eukaryotic ribosomes lost in translation. Nat Rev Mol Cell Biol 13: 727-735.

Grammatikakis I, Abdelmohsen K, Gorospe M. 2017. Posttranslational control of HuR function. Wiley Interdiscip Rev RNA 8: e1372.

Grudzien-Nogalska E, Kiledjian M. 2017. New insights into decapping enzymes and selective mRNA decay. Wiley Interdiscip Rev RNA 8: e1379.

Guydosh NR, Green R. 2017. Translation of poly(A) tails leads to precise mRNA cleavage. RNA 23: 749-761.

Habacher C, Guo Y, Venz R, Kumari P, Neagu A, Gaidatzis D, Harvald E, Færgeman N, Gut H, Ciosk R. 2016. Ribonuclease-mediated control of body fat. Dev Cell 39: 359369.

Hafner M, Landthaler M, Burger L, Khorshid M, Hausser J, Berninger P, Rothballer A, Ascano M, Jungkamp A-C, Munschauer M, et al. 2010. Transcriptome-wide Identification of RNA-binding protein and microRNA target sites by PAR-CLIP. Cell 141: 129-141.

Haimovich G, Medina DA, Causse SZ, Garber M, MillanZambrano G, Barkai O, Chavez S, Perez-Ortin JE, Dar zacq X, Choder M. 2013. Gene expression is circular: Factors for mRNA degradation also foster mRNA synthesis. Cell 153: 1000-1011.

Harigaya Y, Parker R. 2017. The link between adjacent codon pairs and mRNA stability. BMC Genomics 18: 364 .

Horikawa W, Endo K, Wada M, Ito K. 2016. Mutations in the G-domain of Ski7 cause specific dysfunction in nonstop decay. Sci Rep 6: 29295.

Hu W, Sweet TJ, Chamnongpol S, Baker KE, Coller J. 2009. Co-translational mRNA decay in Saccharomyces cerevisiae. Nature 461: 225-229.

Hu W, Petzold C, Coller J, Baker KE. 2010. Nonsense-mediated mRNA decapping occurs on polyribosomes in Saccharomyces cerevisiae. Nat Struct Mol Biol 17: 244-247.

Huch S, Nissan T. 2014. Interrelations between translation and general mRNA degradation in yeast. Wiley Interdiscip Rev RNA 5: 747-763.

Inada T, Aiba H. 2005. Translation of aberrant mRNAs lacking a termination codon or with a shortened $3^{\prime}$-UTR is repressed after initiation in yeast. EMBO J 24: 1584-1595.

Ito-Harashima S, Kuroha K, Tatematsu T, Inada T. 2007. Translation of the poly(A) tail plays crucial roles in nonstop mRNA surveillance via translation repression and protein destabilization by proteasome in yeast. Genes Dev 21: 519-524.

Iwasaki H, Takeuchi O, Teraguchi S, Matsushita K, Uehata T, Kuniyoshi K, Satoh T, Saitoh T, Matsushita M, Standley $\mathrm{DM}$, et al. 2011. The IкB kinase complex regulates the stability of cytokine-encoding mRNA induced by TLRIL-1R by controlling degradation of regnase-1. Nat Immunol 12: 1167-1175.

Jamar NH, Kritsiligkou P, Grant CM. 2017. The nonstop decay mRNA surveillance pathway is required for oxidative stress tolerance. Nucleic Acids Res 45: 6881-6893.

Jangra RK, Yi M, Lemon SM. 2010. DDX6 (Rck/p54) is required for efficient hepatitis $\mathrm{C}$ virus replication but not for internal ribosome entry site-directed translation. J Virol 84: 6810-6824.
Jiao X, Doamekpor SK, Bird JG, Nickels BE, Tong L, Hart RP, Kiledjian M. 2017. 5' end nicotinamide adenine dinucleotide cap in human cells promotes RNA decay through DXO-mediated deNADding. Cell 168: 10151027.e10.

Jonas S, Christie M, Peter D, Bhandari D, Loh B, Huntzinger E, Weichenrieder O, Izaurralde E. 2014. An asymmetric PAN3 dimer recruits a single PAN2 exonuclease to mediate mRNA deadenylation and decay. Nat Struct Mol Biol 21: 599-608.

Jones CI, Zabolotskaya MV, Newbury SF. 2012. The $5^{\prime} \rightarrow 3^{\prime}$ exoribonuclease XRN1/Pacman and its functions in cellular processes and development. Wiley Interdiscip Rev RNA 3: 455-468.

Jungfleisch J, Chowdhury A, Alves-Rodrigues I, Tharun S, Diez J. 2015. The Lsm1-7-Pat1 complex promotes viral RNA translation and replication by differential mechanisms. RNA 21: 1469-1479.

Juszkiewicz S, Hegde RS. 2017. Initiation of quality control during poly $(\mathrm{A})$ translation requires site-specific ribosome ubiquitination. Mol Cell 65: 743-750.

Kamenska A, Simpson C, Vindry C, Broomhead H, Bénard M, Ernoult-Lange M, Lee BP, Harries LW, Weil D, Standart N. 2016. The DDX6-4E-T interaction mediates translational repression and P-body assembly. Nucleic Acids Res 44: 6318-6334.

* Karousis ED, Mühlemann O. 2017. NMD begins where translation ends. Cold Spring Harb Perspect Biol doi: 10.1101/cshperspect.a032862.

Kaufman DR, Papillon J, Larose L, Iwawaki T, Cybulsky AV. 2017. Deletion of inositol-requiring enzyme- $1 \alpha$ in podocytes disrupts glomerular capillary integrity and autophagy. Mol Biol Cell 28: 1636-1651.

Khawaja A, Vopalensky V, Pospisek M. 2015. Understanding the potential of hepatitis $\mathrm{C}$ virus internal ribosome entry site domains to modulate translation initiation via their structure and function. Wiley Interdiscip Rev RNA 6: 211-224.

Kim HH, Kuwano Y, Srikantan S, Lee EK, Martindale JL, Gorospe M. 2009. HuR recruits let-7/RISC to repress cMyc expression. Genes Dev 23: 1743-1748.

Kim Y, Noren Hooten N, Dluzen DF, Martindale JL, Gorospe M, Evans MK. 2015. Posttranscriptional regulation of the inflammatory marker C-reactive protein by the RNA-binding protein $\mathrm{HuR}$ and microRNA 637. $\mathrm{Mol}$ Cell Biol 35: 4212-4221.

Klauer AA, van Hoof A. 2012. Degradation of mRNAs that lack a stop codon: A decade of nonstop progress. Wiley Interdiscip Rev RNA 3: 649-660.

Kobayashi K, Ishitani R, Nureki O. 2013. Recent structural studies on Dom34/aPelota and Hbs1/aEF1 $\alpha$ : Important factors for solving general problems of ribosomal stall in translation. Biophysics (Oxf) 9: 131-140.

Koeller DM, Horowitz JA, Casey JL, Klausner RD, Harford JB. 1991. Translation and the stability of mRNAs encoding the transferrin receptor and c-fos. Proc Natl Acad Sci 88: 7778-7782.

Kojima S, Gendreau KL, Sher-Chen EL, Gao P, Green CB. 2015. Changes in poly(A) tail length dynamics from the loss of the circadian deadenylase Nocturnin. Sci Rep 5: 17059 . 
A.M. Heck and J. Wilusz

Kowalinski E, Schuller A, Green R, Conti E. 2015. Saccharomyces cerevisiae Ski7 is a GTP-binding protein adopting the characteristic conformation of active translational GTPases. Structure 23: 1336-1343.

Kowalinski E, Kögel A, Ebert J, Reichelt P, Stegmann E, Habermann B, Conti E. 2016. Structure of a cytoplasmic 11-subunit RNA exosome complex. Mol Cell 63: 125134.

Kullmann M, Göpfert U, Siewe B, Hengst L. 2002. ELAV/Hu proteins inhibit p27 translation via an IRES element in the p27 5'UTR. Genes Dev 16: 3087-3099.

Kuroha K, Akamatsu M, Dimitrova L, Ito T, Kato Y, Shirahige K, Inada T. 2010. Receptor for activated C kinase 1 stimulates nascent polypeptide-dependent translation arrest. EMBO Rep 11: 956-961.

Kuzuoğlu-Öztürk D, Bhandari D, Huntzinger E, Fauser M, Helms S, Izaurralde E. 2016. miRISC and the CCR4/NOT complex silence mRNA targets independently of $43 \mathrm{~S}$ ribosomal scanning. EMBO J 35: 1186-1203.

Łabno A, Warkocki Z, Kuliński T, Krawczyk PS, Bijata K, Tomecki R, Dziembowski A. 2016. Perlman syndrome nuclease DIS3L2 controls cytoplasmic noncoding RNAs and provides surveillance pathway for maturing snRNAs. Nucleic Acids Res 44: 10437-10453.

LaGrandeur T, Parker R. 1999. The cis acting sequences responsible for the differential decay of the unstable MFA2 and stable PGK1 transcripts in yeast include the context of the translational start codon. RNA 5: 420-433.

Laird-Offringa IA, de Wit CL, Elfferich P, van der Eb AJ. 1990. Poly(A) tail shortening is the translation-dependent step in c-myc mRNA degradation. Mol Cell Biol 10: 61326140.

Lal A, Mazan-Mamczarz K, Kawai T, Yang X, Martindale JL, Gorospe M. 2004. Concurrent versus individual binding of HuR and AUF1 to common labile target mRNAs. EMBO J 23: 3092-3102.

Lee HC, Choe J, Chi SG, Kim YK. 2009. Exon junction complex enhances translation of spliced mRNAs at multiple steps. Biochem Biophys Res Commun 384: 334-340.

Li X, Ohmori T, Irie K, Kimura Y, Suda Y, Mizuno T, Irie K. 2016. Different regulations of ROM2 and LRG1 expression by Ccr4, Pop2, and Dhh1 in the Saccharomyces cerevisiae cell wall integrity pathway. mSphere 1: e00250-16.

Lin JY, Brewer G, Li ML. 2015. HuR and Ago2 bind the internal ribosome entry site of enterovirus 71 and promote virus translation and replication. PLOS ONE 10: e0140291.

Linial M, Gunderson N, Groudine M. 1985. Enhanced transcription of c-myc in bursal lymphoma cells requires continuous protein synthesis. Science 230: 1126-1132.

Liu SW, Rajagopal V, Patel SS, Kiledjian M. 2008. Mechanistic and kinetic analysis of the DcpS scavenger decapping enzyme. J Biol Chem 283: 16427-16436.

Liu L, Ouyang M, Rao JN, Zou T, Xiao L, Chung HK, Wu J, Donahue JM, Gorospe M, Wang JY. 2015. Competition between RNA-binding proteins CELF1 and HuR modulates MYC translation and intestinal epithelium renewal. Mol Biol Cell 26: 1797-1810.

Lu J, Deutsch C. 2008. Electrostatics in the ribosomal tunnel modulate chain elongation rates. J Mol Biol 384: 73-86.
Mak W, Fang C, Holden T, Dratver MB, Lin H. 2016. An important role of Pumilio 1 in regulating the development of the mammalian female germline. Biol Reprod 94: 134.

Maryati M, Airhihen B, Winkler GS. 2015. The enzyme activities of Cafl and Ccr4 are both required for deadenylation by the human Ccr4-Not nuclease module. Biochem J 469: 169-176.

Mason PJ, Bessler M. 2015. mRNA deadenylation and telomere disease. J Clin Invest 125: 1796-1798.

Mathys H, Basquin J, Ozgur S, Czarnocki-Cieciura M, Bonneau F, Aartse A, Dziembowski A, Nowotny M, Conti E, Filipowicz W. 2014. Structural and biochemical insights to the role of the CCR4-NOT complex and DDX6 ATPase in microRNA repression. Mol Cell 54: 751-765.

Mauer J, Luo X, Blanjoie A, Jiao X, Grozhik AV, Patil DP, Linder B, Pickering BF, Vasseur JJ, Chen Q, et al. 2017. Reversible methylation of m6Am in the $5^{\prime}$ cap controls mRNA stability. Nature 541: 371-375.

Mayr C. 2016. Evolution and biological roles of alternative 3'UTRs. Trends Cell Biol 26: 227-237.

Meng Z, King PH, Nabors LB, Jackson NL, Chen CY, Emanuel PD, Blume SW. 2005. The ELAV RNA-stability factor HuR binds the $5^{\prime}$-untranslated region of the human IGF-IR transcript and differentially represses cap-dependent and IRES-mediated translation. Nucleic Acids Res 33: 2962-2979.

Merret R, Nagarajan VK, Carpentier MC, Park S, Favory JJ, Descombin J, Picart C, Charng YY, Green PJ, Deragon JM, et al. 2015. Heat-induced ribosome pausing triggers mRNA co-translational decay in Arabidopsis thaliana. Nucleic Acids Res 43: 4121-4132.

Mishima Y, Tomari Y. 2016. Codon usage and 3' UTR length determine maternal mRNA stability in Zebrafish. Mol Cell 61: 874-885.

Moon SL, Anderson JR, Kumagai Y, Wilusz CJ, Akira S, Khromykh AA, Wilusz J. 2012. A noncoding RNA produced by arthropod-borne flaviviruses inhibits the cellular exoribonuclease XRN1 and alters host mRNA stability. RNA 18: 2029-2040.

Moon SL, Blackinton JG, Anderson JR, Dozier MK, Dodd BJT, Keene JD, Wilusz CJ, Bradrick SS, Wilusz J. 2015 XRN1 stalling in the $5^{\prime}$ UTR of hepatitis $C$ virus and bovine viral diarrhea virus is associated with dysregulated host mRNA stability. PLOS Pathog 11: e1004708.

Moore K, Hollien J. 2015. Ire1-mediated decay in mammalian cells relies on mRNA sequence, structure, and translational status. Mol Biol Cell 26: 2873-2884.

Morris AR, Mukherjee N, Keene JD. 2008. Ribonomic analysis of human Pum1 reveals cis-trans conservation across species despite evolution of diverse mRNA target sets. Mol Cell Biol 28: 4093-4103.

Mugler CF, Hondele M, Heinrich S, Sachdev R, Vallotton P, Koek AY, Chan LY, Weis K. 2016. ATPase activity of the DEAD-box protein Dhh1 controls processing body formation. eLife 5: e18746.

Naudin C, Hattabi A, Michelet F, Miri-Nezhad A, Benyoucef A, Pflumio F, Guillonneau F, Fichelson S, Vigon I, Dusanter-Fourt I, et al. 2017. PUMILIO/FOXP1 signaling drives expansion of hematopoietic stem/progenitor and leukemia cells. Blood 129: 2493-2506. 
Neymotin B, Ettore V, Gresham D. 2016. Multiple transcript properties related to translation affect mRNA degradation rates in Saccharomyces cerevisiae. G3 doi: 10.1534/ g3.116.032276.

Ng CKL, Shboul M, Taverniti V, Bonnard C, Lee H, Eskin A, Nelson SF, Al-Raqad M, Altawalbeh S, Séraphin B, et al. 2015. Loss of the scavenger mRNA decapping enzyme DCPS causes syndromic intellectual disability with neuromuscular defects. Hum Mol Genet 24: 3163-3171.

Nicklas S, Okawa S, Hillje A-L, González-Cano L, Del Sol A, Schwamborn JC. 2015. The RNA helicase DDX6 regulates cell-fate specification in neural stem cells via miRNAs. Nucleic Acids Res 43: 2638-2654.

Niedzwiecka A, Nilsson P, Worch R, Stepinski J, Darzynkiewicz E, Virtanen A. 2016. Molecular recognition of mRNA $5^{\prime}$ cap by $3^{\prime}$ poly(A)-specific ribonuclease (PARN) differs from interactions known for other capbinding proteins. Biochim Biophys Acta 1864: 331-345.

Niinuma S, Fukaya T, Tomari Y. 2016. CCR4 and CAF1 deadenylases have an intrinsic activity to remove the post-poly(A) sequence. RNA 22: 1550-1559.

Nishimura T, Padamsi Z, Fakim H, Milette S, Dunham WH, Gingras AC, Fabian MR. 2015. The eIF4E-binding protein $4 \mathrm{E}-\mathrm{T}$ is a component of the mRNA decay machinery that bridges the $5^{\prime}$ and $3^{\prime}$ termini of target mRNAs. Cell Rep 11: 1425-1436.

Onouchi H, Nagami Y, Haraguchi Y, Nakamoto M, Nishimura Y, Sakurai R, Nagao N, Kawasaki D, Kadokura Y, Naito S. 2005. Nascent peptide-mediated translation elongation arrest coupled with mRNA degradation in the CGS1 gene of Arabidopsis. Genes Dev 19: 1799-1810.

Orban TI, Izaurralde E. 2005. Decay of mRNAs targeted by RISC requires XRN1, the Ski complex, and the exosome. RNA 11: 459-469.

Ørom UA, Nielsen FC, Lund AH. 2008. MicroRNA-10a binds the $5^{\prime}$ UTR of ribosomal protein mRNAs and enhances their translation. Mol Cell 30: 460-471.

Ostareck DH, Naarmann-de Vries IS, Ostareck-Lederer A. 2014. DDX6 and its orthologs as modulators of cellular and viral RNA expression. Wiley Interdiscip Rev RNA 5: 659-678.

Ozgur S, Basquin J, Kamenska A, Filipowicz W, Standart N, Conti E. 2015. Structure of a human 4E-T/DDX6/ CNOT1 complex reveals the different interplay of DDX6-binding proteins with the CCR4-NOT complex. Cell Rep 13: 703-711.

Park JH, Shin C. 2014. MicroRNA-directed cleavage of targets: Mechanism and experimental approaches. BMB Rep 47: 417-423.

Park OH, Park J, Yu M, An HT, Ko J, Kim YK. 2016. Identification and molecular characterization of cellular factors required for glucocorticoid receptor-mediated mRNA decay. Genes Dev 30: 2093-2105.

Pashler AL, Towler BP, Jones CI, Newbury SF. 2016. The roles of the exoribonucleases DIS3L2 and XRN1 in human disease. Biochem Soc Trans 44: 1377-1384.

Passos DO, Doma MK, Shoemaker CJ, Muhlrad D, Green R, Weissman J, Hollien J, Parker R. 2009. Analysis of Dom34 and its function in no-go decay. Mol Biol Cell 20: 3025 3032.
Pelechano V, Wei W, Steinmetz LM. 2015. Widespread cotranslational RNA decay reveals ribosome dynamics. Cell 161: 1400-1412.

Pelechano V, Wei W, Steinmetz LM. 2016. Genome-wide quantification of $5^{\prime}$-phosphorylated mRNA degradation intermediates for analysis of ribosome dynamics. Nat Protoc 11: 359-376.

Pereira FJC, Teixeira A, Kong J, Barbosa C, Silva AL, Marques-Ramos A, Liebhaber SA, Romão L. 2015. Resistance of mRNAs with AUG-proximal nonsense mutations to nonsense-mediated decay reflects variables of mRNA structure and translational activity. Nucleic Acids Res 43: 6528-6544.

Pirouz M, Du P, Munafò M, Gregory R. 2016. Dis312-mediated decay is a quality control pathway for noncoding RNAs. Cell Rep 16: 1861-1873.

Pisareva VP, Skabkin MA, Hellen CU, Pestova TV, Pisarev AV. 2011. Dissociation by Pelota, Hbs1 and ABCE1 of mammalian vacant $80 \mathrm{~S}$ ribosomes and stalled elongation complexes. EMBO J 30: 1804-1817.

Presnyak V, Alhusaini N, Chen YH, Martin S, Morris N, Kline N, Olson S, Weinberg D, Baker KE, Graveley BR, et al. 2015. Codon optimality is a major determinant of mRNA stability. Cell 160: 1111-1124.

Radhakrishnan A, Green R. 2016. Connections underlying translation and mRNA stability. J Mol Biol 428: 35583564.

Radhakrishnan A, Chen YH, Martin S, Alhusaini N, Green R, Coller J. 2016. The DEAD-Box protein Dhhlp couples mRNA decay and translation by monitoring codon optimality. Cell 167: 122-132.e9.

Rahmsdorf HJ, Schönthal A, Angel P, Litfin M, Rüther U, Herrlich P. 1987. Posttranscriptional regulation of c-fos mRNA expression. Nucleic Acids Res 15: 1643-1659.

Rath S, Donovan J, Whitney G, Chitrakar A, Wang W, Korennykh A. 2015. Human RNase L tunes gene expression by selectively destabilizing the microRNA-regulated transcriptome. Proc Natl Acad Sci 112: 15916-15921.

Rissland OS, Norbury CJ. 2009. Decapping is preceded by $3^{\prime}$ uridylation in a novel pathway of bulk mRNA turnover. Nat Struct Mol Biol 16: 616-623.

Roberts APE, Lewis AP, Jopling CL. 2011. miR-122 activates hepatitis $\mathrm{C}$ virus translation by a specialized mechanism requiring particular RNA components. Nucleic Acids Res 39: 7716-7729.

Rouya C, Siddiqui N, Morita M, Duchaine TF, Fabian MR, Sonenberg N. 2014. Human DDX6 effects miRNA-mediated gene silencing via direct binding to CNOT1. RNA 20: 1398-1409.

Russo J, Olivas WM. 2015. Conditional regulation of Puflp, Puf4p, and Puf5p activity alters YHB1 mRNA stability for a rapid response to toxic nitric oxide stress in yeast. $\mathrm{Mol}$ Biol Cell 26: 1015-1029.

Ryseck RP, Hirai SI, Yaniv M, Bravo R. 1988. Transcriptional activation of c-jun during the $\mathrm{G}_{0} / \mathrm{G}_{1}$ transition in mouse fibroblasts. Nature 334: 535-537.

Saito S, Hosoda N, Hoshino S. 2013. The Hbs1-Dom34 protein complex functions in Non-stop mRNA decay in mammalian cells. J Biol Chem 288: 17832-17843.

Schäfer IB, Rode M, Bonneau F, Schüssler S, Conti E. 2014. The structure of the Pan2-Pan3 core complex reveals 
A.M. Heck and J. Wilusz

cross-talk between deadenylase and pseudokinase. Nat Struct Mol Biol 21: 591-598.

Scheel TKH, Luna JM, Liniger M, Nishiuchi E, Rozen-Gagnon K, Shlomai A, Auray G, Gerber M, Fak J, Keller I, et al. 2016. A broad RNA virus survey reveals both miRNA dependence and functional sequestration. Cell Host Microbe 19: 409-423.

Schwamborn JC, Berezikov E, Knoblich JA. 2009. The TRIM-NHL protein TRIM32 activates microRNAs and prevents self-renewal in mouse neural progenitors. Cell 136: 913-925.

Serman A, Le Roy F, Aigueperse C, Kress M, Dautry F, Weil D. 2007. GW body disassembly triggered by siRNAs independently of their silencing activity. Nucleic Acids Res 35: 4715-4727.

Shan B, Wang X, Wu Y, Xu C, Xia Z, Dai J, Shao M, Zhao F, He S, Yang L, et al. 2017. The metabolic ER stress sensor IRE1a suppresses alternative activation of macrophages and impairs energy expenditure in obesity. Nat Immunol 18: $519-529$.

Sharif H, Ozgur S, Sharma K, Basquin C, Urlaub H, Conti E. 2013. Structural analysis of the yeast Dhh1/Pat complex reveals how Dhh1 engages Pat1, Edc3 and RNA in mutually exclusive interactions. Nucleic Acids Res 41: 83778390.

Sharifnia P, Jin Y. 2014. Regulatory roles of RNA binding proteins in the nervous system of C. elegans. Front $\mathrm{Mol}$ Neurosci 7: 100.

Shimakami T, Yamane D, Jangra RK, Kempf BJ, Spaniel C, Barton DJ, Lemon SM. 2012. Stabilization of hepatitis C virus RNA by an Ago2-miR-122 complex. Proc Natl Acad Sci 109: 941-946.

Shoemaker CJ, Eyler DE, Green R. 2010. Dom34:Hbs1 promotes subunit dissociation and peptidyl-tRNA drop-off to initiate no-go decay. Science 330: 369-372.

Simms CL, Thomas EN, Zaher HS. 2017. Ribosome-based quality control of mRNA and nascent peptides. Wiley Interdiscip Rev RNA 8: e1366.

Skeparnias I, Anastasakis D, Shaukat AN, Grafanaki K, Stathopoulos C. 2017. Expanding the repertoire of deadenylases. RNA Biol 1-6.

Song MG, Kiledjian M. 2007. 3' Terminal oligo U-tract-mediated stimulation of decapping. RNA 13: 2356-2365.

Stimac E, Groppi VE, Coffino P. 1983. Increased histone mRNA levels during inhibition of protein synthesis. Biochem Biophys Res Commun 114: 131-137.

Stowell JAW, Webster MW, Kögel A, Wolf J, Shelley KL, Passmore LA. 2016. Reconstitution of targeted deadenylation by the Ccr4-Not complex and the YTH domain protein Mmil. Cell Rep 17: 1978-1989.

Sun M, Schwalb B, Pirkl N, Maier KC, Schenk A, Failmezger H, Tresch A, Cramer P. 2013. Global analysis of eukaryotic mrna degradation reveals Xrn1-dependent buffering of transcript levels. Mol Cell 52: 52-62.

Sun S, Zhang X, Lyu L, Li X, Yao S, Zhang J. 2016. Autotaxin expression is regulated at the post-transcriptional level by the RNA-binding proteins HuR and AUF1. J Biol Chem 291: 25823-25836.

Sweet T, Kovalak C, Coller J, Kiktev D, Inge-Vechtomov S 2012. The DEAD-Box protein Dhh1 promotes decapping by slowing ribosome movement. PLoS Biol 10: e1001342.
Tavernier SJ, Osorio F, Vandersarren L, Vetters J, Vanlangenakker N, Van Isterdael G, Vergote K, De Rycke R, Parthoens E, van de Laar L, et al. 2017. Regulated IRE1-dependent mRNA decay sets the threshold for dendritic cell survival. Nat Cell Biol 19: 698-710.

Taverniti V, Seraphin B. 2015. Elimination of cap structures generated by mRNA decay involves the new scavenger mRNA decapping enzyme Aph1/FHIT together with DcpS. Nucleic Acids Res 43: 482-492.

Thomas MP, Liu X, Whangbo J, McCrossan G, Sanborn KB, Basar E, Walch M, Lieberman J. 2015. Apoptosis triggers specific, rapid, and global mRNA decay with $3^{\prime}$ uridylated intermediates degraded by DIS3L2. Cell Rep 11: 10791089.

Thomas SP, Kim E, Kim J-S, Raines RT. 2016. Knockout of the ribonuclease inhibitor gene leaves human cells vulnerable to secretory ribonucleases. Biochemistry 55: 6359-6362.

Thompson CB, Challoner PB, Neiman PE, Groudine M. 1986. Expression of the $c-m y b$ proto-oncogene during cellular proliferation. Nature 319: 374-380.

Tian B, Manley JL. 2017. Alternative polyadenylation of mRNA precursors. Nat Rev Mol Cell Biol 18: 18-30.

Tsuboi T, Kuroha K, Kudo K, Makino S, Inoue E, Kashima I, Inada T. 2012. Dom34:Hbs1 plays a general role in quality-control systems by dissociation of a stalled ribosome at the $3^{\prime}$ end of aberrant mRNA. Mol Cell 46: 518-529.

Turner JD, Vernocchi S, Schmitz S, Muller CP. 2014. Role of the $5^{\prime}$-untranslated regions in post-transcriptional regulation of the human glucocorticoid receptor. Biochim Biophys Acta 1839: 1051-1061.

Uehata T, Takeuchi O. 2017. Regnase-1 is an endoribonuclease essential for the maintenance of immune homeostasis. J Interf Cytokine Res 37: 220-229.

Ustianenko D, Pasulka J, Feketova Z, Bednarik L, Zigackova D, Fortova A, Zavolan M, Vanacova S. 2016. TUTDIS3L2 is a mammalian surveillance pathway for aberrant structured non-coding RNAs. EMBO J 35: 21792191.

Valkov E, Jonas S, Weichenrieder O. 2017. Mille viae in eukaryotic mRNA decapping. Curr Opin Struct Biol 47: $40-51$.

van Hoof A. 2005. Conserved functions of yeast genes support the duplication, degeneration and complementation model for gene duplication. Genetics 171: 1455-1461.

van Hoof A, Frischmeyer PA, Dietz HC, Parker R. 2002. Exosome-mediated recognition and degradation of mRNAs lacking a termination codon. Science 295: 2262-2264.

Viegas SC, Silva IJ, Apura P, Matos RG, Arraiano CM. 2015. Surprises in the $3^{\prime}$-end: “U” can decide too! FEBS J 282: 3489-3499.

Virtanen A, Henriksson N, Nilsson P, Nissbeck M. 2013. Poly(A)-specific ribonuclease (PARN): An allosterically regulated, processive and mRNA cap-interacting deadenylase. Crit Rev Biochem Mol Biol 48: 192-209.

Wahle E, Winkler GS. 2013. RNA decay machines: Deadenylation by the Ccr4/Not and Pan2/Pan 3 complexes. Biochim Biophys Acta - Gene Regul Mech 1829: 561-570.

Wang Y, Arribas-Layton M, Chen Y, Lykke-Andersen J, Sen GLL. 2015. DDX6 orchestrates mammalian progenitor 
function through the mRNA degradation and translation pathways. Mol Cell 60: 118-130.

Weidmann CA, Raynard NA, Blewett NH, Van Etten J, Goldstrohm AC. 2014. The RNA binding domain of Pumilio antagonizes poly-adenosine binding protein and accelerates deadenylation. RNA 20: 1298-1319.

Weingarten-Gabbay S, Elias-Kirma S, Nir R, Gritsenko AA, Stern-Ginossar N, Yakhini Z, Weinberger A, Segal E. 2016. Systematic discovery of cap-independent translation sequences in human and viral genomes. Science 351: aad4939.

White EJF, Matsangos AE, Wilson GM. 2017. AUF1 regulation of coding and noncoding RNA. Wiley Interdiscip Rev RNA 8: e1393.

Wilson JA, Zhang C, Huys A, Richardson CD. 2011. Human Ago2 is required for efficient microRNA 122 regulation of hepatitis $\mathrm{C}$ virus RNA accumulation and translation. $J$ Virol 85: 2342-2350.

Wilusz CJ, Wilusz J. 2013. Lsm proteins and Hfq. RNA Biol 10: $592-601$.

Wolf J, Passmore LA. 2014. mRNA deadenylation by Pan2Pan3. Biochem Soc Trans 42: 184-187.

Wolf J, Valkov E, Allen MD, Meineke B, Gordiyenko Y, McLaughlin SH, Olsen TM, Robinson CV, Bycroft M, Stewart M, et al. 2014. Structural basis for Pan3 binding to Pan 2 and its function in mRNA recruitment and deadenylation. EMBO J 33: 1514-1526.

Woodward LA, Mabin JW, Gangras P, Singh G. 2017. The exon junction complex: A lifelong guardian of mRNA fate. Wiley Interdiscip Rev RNA 8: el411.

Wurm JP, Holdermann I, Overbeck JH, Mayer PHO, Sprangers R. 2017. Changes in conformational equilibria regulate the activity of the Dcp2 decapping enzyme. Proc Natl Acad Sci 114: 6034-6039.

Xi R, Doan C, Liu D, Xie T. 2005. Pelota controls self-renewal of germline stem cells by repressing a Bam-independent differentiation pathway. Development 132: 5365-5374.

Yamaji M, Jishage M, Meyer C, Suryawanshi H, Der E, Yamaji M, Garzia A, Morozov P, Manickavel S, McFarland HL, et al. 2017. DND1 maintains germline stem cells via recruitment of the CCR4-NOT complex to target mRNAs. Nature 543: 568-572.

Yeh CH, Hung LY, Hsu C, Le SY, Lee PT, Liao WL, Lin YT, Chang WC, Tseng JT. 2008. RNA-binding protein HuR interacts with thrombomodulin $5^{\prime}$ untranslated region and represses internal ribosome entry site-mediated translation under IL-1 $\beta$ treatment. Mol Biol Cell 19: 3812-3822.
Yoshinaga M, Nakatsuka Y, Vandenbon A, Ori D, Uehata T Tsujimura T, Suzuki Y, Mino T, Takeuchi O. 2017. Regnase-1 maintains iron homeostasis via the degradation of transferrin receptor 1 and prolyl-hydroxylase-domaincontaining protein 3 mRNAs. Cell Rep 19: 1614-1630.

Yu TX, Rao JN, Zou T, Liu L, Xiao L, Ouyang M, Cao S, Gorospe M, Wang JY. 2013. Competitive binding of CUGBP1 and HuR to occludin mRNA controls its translation and modulates epithelial barrier function. Mol Biol Cell 24: 85-99.

Yu CH, Dang Y, Zhou Z, Wu C, Zhao F, Sachs MS, Liu Y. 2015. Codon usage influences the local rate of translation elongation to regulate cotranslational protein folding. Mol Cell 59: 744-754.

Zamore PD, Williamson JR, Lehmann R. 1997. The Pumilio protein binds RNA through a conserved domain that defines a new class of RNA-binding proteins. RNA 3: 1421-1433.

Zhang C, Huys A, Thibault PA, Wilson JA. 2012. Requirements for human Dicer and TRBP in microRNA-122 regulation of HCV translation and RNA abundance. $\mathrm{Vi}$ rology 433: 479-488.

Zhang Z, Huang A, Zhang A, Zhou C. 2017. HuR promotes breast cancer cell proliferation and survival via binding to CDK3 mRNA. Biomed Pharmacother 91: 788-795.

Zhao F, Yu C, Liu Y. 2017. Codon usage regulates protein structure and function by affecting translation elongation speed in Drosophila cells. Nucleic Acids Res doi: 10.1093/ nar/gkx501.

Zhou M, Bail S, Plasterer HL, Rusche J, Kiledjian M. 2015. DcpS is a transcript-specific modulator of RNA in mammalian cells. RNA 21: 1306-1312.

Zhuang R, Rao JN, Zou T, Liu L, Xiao L, Cao S, Hansraj NZ, Gorospe M, Wang JY. 2013. miR-195 competes with HuR to modulate stim1 mRNA stability and regulate cell migration. Nucleic Acids Res 41: 7905-7919.

Ziemniak M, Mugridge JS, Kowalska J, Rhoads RE, Gross JD, Jemielity J. 2016. Two-headed tetraphosphate cap analogs are inhibitors of the Dcp1/2 RNA decapping complex. RNA 22: 518-529.

Zinder JC, Lima CD. 2017. Targeting RNA for processing or destruction by the eukaryotic RNA exosome and its cofactors. Genes Dev 31: 88-100.

Zinder JC, Wasmuth E V, Lima CD. 2016. Nuclear RNA exosome at $3.1 \AA$ reveals substrate specificities, RNA paths, and allosteric inhibition of Rrp44/Dis3. Mol Cell 64: 734-745. 


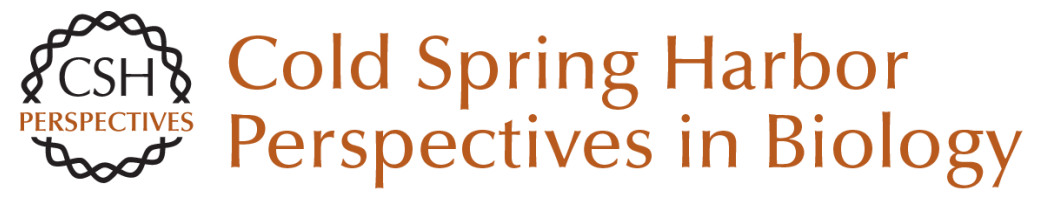

\section{The Interplay between the RNA Decay and Translation Machinery in Eukaryotes}

Adam M. Heck and Jeffrey Wilusz

Cold Spring Harb Perspect Biol 2018; doi: 10.1101/cshperspect.a032839 originally published online January 8, 2018

\section{Subject Collection Translation Mechanisms and Control}

Protein Synthesis and Translational Control: A

Historical Perspective

Soroush Tahmasebi, Nahum Sonenberg, John

W.B. Hershey, et al.

Translational Control in the Brain in Health and

Disease

Wayne S. Sossin and Mauro Costa-Mattioli

Phosphorylation and Signal Transduction

Pathways in Translational Control Christopher G. Proud

Translational Control during Developmental

Transitions

Felipe Karam Teixeira and Ruth Lehmann

Stress Granules and Processing Bodies in

Translational Control

Pavel Ivanov, Nancy Kedersha and Paul Anderson

Fluorescence Imaging Methods to Investigate

Translation in Single Cells Jeetayu Biswas, Yang Liu, Robert H. Singer, et al.

Translational Control in Virus-Infected Cells Noam Stern-Ginossar, Sunnie R. Thompson, Michael B. Mathews, et al.

Nonsense-Mediated mRNA Decay Begins Where Translation Ends

Evangelos D. Karousis and Oliver Mühlemann
Principles of Translational Control John W.B. Hershey, Nahum Sonenberg and Michael B. Mathews

The Epitranscriptome in Translation Regulation Eyal Peer, Sharon Moshitch-Moshkovitz, Gideon Rechavi, et al.

Translational Control in Cancer Nathaniel Robichaud, Nahum Sonenberg, Davide Ruggero, et al.

Roles of Long Noncoding RNAs and Circular

RNAs in Translation Marina Chekulaeva and Nikolaus Rajewsky

Ribosome Profiling: Global Views of Translation Nicholas T. Ingolia, Jeffrey A. Hussmann and Jonathan S. Weissman

Noncanonical Translation Initiation in Eukaryotes Thaddaeus Kwan and Sunnie R. Thompson

Mechanistic Insights into MicroRNA-Mediated Gene Silencing Thomas F. Duchaine and Marc R. Fabian

Toward a Kinetic Understanding of Eukaryotic Translation Masaaki Sokabe and Christopher S. Fraser

For additional articles in this collection, see http://cshperspectives.cshlp.org/cgi/collection/

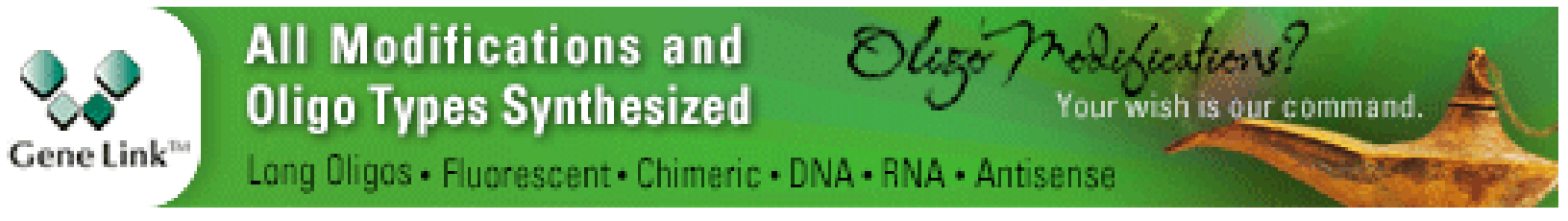


For additional articles in this collection, see http://cshperspectives.cshlp.org/cgi/collection/

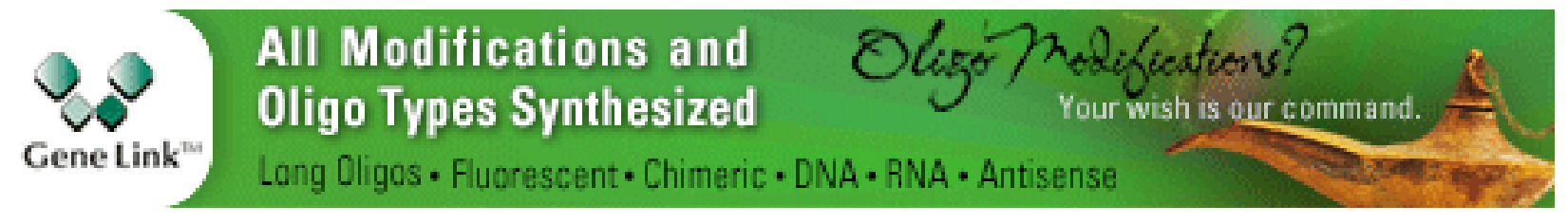

Copyright @ 2018 Cold Spring Harbor Laboratory Press; all rights reserved 